\title{
THE UNFINISHED BUSINESS OF REGULATING CLEARINGHOUSES
}

\author{
Paolo Saguato*
}

Financial derivatives have been widely blamed for causing the 2008 financial crisis. These complex instruments created a deep and opaque web of bilateral links between major financial institutions that contributed to the transmission of systemic risk throughout financial markets. In order to stabilize the derivatives markets, legislators included radical provisions in the Dodd-Frank Wall Street Reform Act of 2010. As a result, traders are now required to process derivatives through clearinghouses: specialized risk managers that act as middlemen between buyers and sellers and guarantee each party's performance.

Policymakers believed that clearinghouses would provide much-needed stability in derivatives markets by acting as designated systemic risk managers. However, this Article argues

* Assistant Professor of Law, George Mason University, Antonin Scalia Law School. I am grateful for comments and conversation at workshops at the Center for International Governance Innovation, Systemic Risk in the Financial Sector: Ten Years after the Global, Financial Crisis Conference (May 2018), the 2019 AALS Financial Institutions Section Panel (January 2019), Fordham School of Law (February 2019), the Junior Business Law Conference at the University of Colorado Law School (July 2019), George Mason University Antonin Scalia Law School (August 2019), Penn State Law (February 2020) and with Anat Admati, Emilios Avgouleas, Chris Bradley, Vincent Buccola, Felix Chang, Sean J. Griffith, Cathey Hwang, Ben Johnson, Jeremy Kress, John McGinnis, William Magnuson, Robert T. Miller, William Moon, David Murphy, Richard Squire, Roberta Romano, Steven Schwarcz, Heidi Mandanis Schooner, and J.W. Verret. Thanks also to my excellent research assistants, Tom Momberg and Ross Broudy, for their hard work and research librarian, Pete Vay, for his invaluable support. A special thanks to Barrie Kreinik for her excellent editing work. Finally, I am grateful to the editors of the Columbia Business Law Review for their excellent editorial assistance on this Article, especially Zachary Barker, Dustin Graber, and Mackenzie Humble. All errors are entirely my own. Comments to psaguato@gmu.edu. 
that the effect of clearinghouses on systemic risk is less clearcut than scholars and policymakers have generally believed. While clearinghouses have removed much of the financial risk from markets, they have simultaneously concentrated it within their own walls. Yet, these walls stand on fragile foundations: the economic and governance incentives of clearinghouses and their stakeholders are misaligned, which could undermine their systemic resilience.

This Article contends that the current regulatory framework has critical, overlooked flaws that exacerbate clearinghouses' moral hazard while creating new, risky, too-big-to-fail institutions. It urges policymakers to intervene: in order to rectify this situation, financial regulators must do more to ensure that clearinghouses are bastions of financial stability and not systemic risk amplifiers. The implementation of a multi-stakeholder board and the creation of hybrid financial instruments to complement the capital structure of clearinghouses are the first steps toward enhancing the accountability and systemic resilience of these critical market infrastructures.

I. Introduction

II. Clearinghouses: Economics and Organization

A. The Economics of Central Clearing: What

Clearinghouses Do.

B. The Organization of Clearinghouses: Markets, Ownership, and Governance Structure

III. The Agency Costs of the Member-Shareholder divide .492 IV. The Current Regulatory Framework and Governance Policies For Clearinghouses.

A. The Current Regulatory Landscape of Clearinghouses

B. The Internal Governance of Clearinghouses: An Industry Overview.

V. How to Improve Clearinghouse Resilience: Governance and Capital Regulation

A. Existing Academic Proposals ............................516

B. Some Policy Proposals

1. The Remutualization of Clearinghouses.........522

2. The Nationalization of Clearinghouses. 523 
3. Multi-stakeholder Boards.

4. A New Capital Structure for Clearinghouses: Convertible Debt and Capital Requirements

5. Ring-fencing and Intra-group Guarantee .......527

C. Recovery and Resolution Mechanisms..................528

VI. Conclusion

\section{INTRODUCTION}

In September 2018, on the tenth anniversary of the Lehman Brothers bankruptcy, ${ }^{1}$ events in Grimstad-a small fishing town in Norway_- "shiver[ed] down regulators' spines" all around the world. ${ }^{2}$ Einar Aas, one of Norway's richest men, blew a $€ 114$ million hole in the $€ 166$ million guaranty capital fund of Nasdaq Clearing, a derivatives clearinghouse-a financial firm that insures its members and users against the risk of default. ${ }^{3}$ The failure of the clearinghouse to effectively monitor Mr. Aas's trading positions resulted in more than two-thirds of the firm's available financial resources being used to cover the losses and stabilize the Nordic energy markets. ${ }^{4}$ Interestingly, of the total $€ 114$ million used to support the firm, only $€ 7$ million came from the clearinghouse's own

1 See Philip Stafford \& David Sheppard, Trader Blows €100m Hole in Nasdaq's Nordic Power Market, Fin. Times (Sept. 13, 2018), https://www.ft.com/content/43c74e02-b749-11e8-bbc3-ccd7de085ffe [https://perma.cc/W3DG-F4NN]. See generally LAURENCE M. BALL, THE FED AND LeHMAN BRothers: SetTing The Record Straight on a Financial DisASTER 1-18 (2018) (providing an insightful analysis of the Lehman Brothers' bankruptcy and its effects on the 2008 market crash); CARMEN M. REINHART \& Kenneth S. Rogoff, This Time Is Different: Eight Centuries of FinanCIAL FOLLY (2009) (investigating the causes of financial crises).

2 Flight to Safety: Have Regulators Created A New Type of Financial Monster?, ECONOMIST, June 1, 2019, at 63, 63.

3 See Umar Faruqui et al., Clearing Risks in OTC Derivatives Markets: The CCP-Bank Nexus, BIS Q. REV., Dec. 2018, at 73, 75.

4 See Stafford \& Sheppard, supra note 1. 
capital; all of the remaining $€ 107$ million came from the members of the clearinghouse. ${ }^{5}$

What at first glance seemed to be a regional event that only affected a reasonably small player in the global financial derivatives markets - and did not trigger any systemic shocks or losses-ultimately had significant, if subtle, repercussions on policymakers. It revealed that clearinghouses, the financialfirms that lawmakers embraced as bastions of market stability, ${ }^{6}$ have structural vulnerabilities and can run into trouble. Furthermore, it exposed the shortcomings of the regulatory architecture created in the aftermath of the 2008 financial crisis, showing that it is far from immune to errors, and revealed that the business of regulating clearinghouses, which are systemic risk managers, is still unfinished. As a result of this event, policymakers domestically and globally have embarked on a dialogue with industry participants and the public to discuss the risk management, governance, and resolution practices of clearinghouses, but the road ahead is still a long one. ${ }^{7}$

5 See Faruqui et al., supra note 3, at 75-76. Members of Nasdaq Clearing include banks and other traders such as J.P. Morgan Chase, Morgan Stanley, Citigroup, and UBS, which use Nasdaq Clearing to clear their energy derivatives. See Membership List, NASDAQ, http://www.nasdaqomxnordic.com/membership-list [https://perma.cc/B69Q-Y425] (last visited May 11, 2020); Nasdaq Clearing Member Default on 10 September 2018, NASDAQ, https://business.nasdaq.com/updates-on-the-Nasdaq-Clearing-Member-Default/index.html [https://perma.cc/J4YJ-G6CL] (last visited May 24, 2020) (providing a comprehensive history and analysis of the default event of Einer Aas and of the procedures adopted to manage the default).

6 See Stafford \& Sheppard, supra note 1.

7 The Financial Stability Board published two consultation papers on the financial resources available for clearinghouse resolutions and the treatment of clearinghouses' equity in the resolution process. One of the papers was published in November 2018, and the other was published in November 2020. See Fin. Stability Bd., Financial Resources to Support CCP ResoLUTION AND THE TREATMENT OF CCP EQUiTy IN RESOlUTION (2018), http://www.fsb.org/wp-content/uploads/P151118-2.pdf [https://perma.cc/5RYD-9HN5]; see also Public Responses to Consultation on Financial Resources to Support CCP Resolution and the Treatment of CCP Equity in Resolution, Fin. STABILITY BOARD (Feb. 8, 2019), https://www.fsb.org/2019/02/public-responses-to-consultation-on-financialresources-to-support-ccp-resolution-and-the-treatment-of-ccp-equity-inresolution/[https://perma.cc/6STR-X6GM]; Fin. STABILITY BD., GUIDANCE ON 
This Article identifies in the moral hazard of the separation of ownership rights and final risk bearing obligations the primary source of clearinghouses' potential structural fragility. ${ }^{8}$ It then contributes to the ongoing discussion and enlivens the discourse on clearinghouse resilience, challenging the current regulatory and academic approach to clearinghouses' governance and recovery ${ }^{9}$ and arguing that, if not addressed,

Financial Resources to Support CCP Resolution AND on the Treatment of CCP Equity in Resolution: Consultative Document (2020), https://www.fsb.org/2020/05/guidance-on-financial-resources-to-supportccp-resolution-and-on-the-treatment-of-ccp-equity-in-resolution-consultative-document/ [https://perma.cc/5MMK-Y4CU]. Additionally, the Commodities Futures Trading Commission ("CFTC") organized a Market Risk Advisory Committee meeting in December 2018 to discuss the current risk management and governance practices of central counterparties. See Market Risk Advisory Committee, 83 Fed. Reg. 58,236 (Nov. 19, 2018). In December 2019 Commissioner Rostin Behnam established two subcommittees of the Market Risk Advisory Committee, the Central Counterparty (CCP) Risk and Governance Subcommittee, and the Market Structure Subcommittee, whose primary focus was to be clearinghouse resilience. See Press Release, Commodity Futures Trading Commission, CFTC Commissioner Behnam Announces Two New Subcommittees of the Market Risk Advisory Committee (Dec. 2, 2019), https://www.cftc.gov/PressRoom/PressReleases/8087-19 [https://perma.cc/3XDZ-C9E7].

8 This Article is part of a series of papers investigating the organizational structure of clearinghouses, and the role and accompanying regulations of clearinghouses in modern financial markets. The first companion paper, while embracing insights from the literature on the theory of the firm, documents the historical evolution of the ownership structure of clearinghouses and the costs and benefits of different ownership models. See Paolo Saguato, The Ownership of Clearinghouses: When "Skin in the Game" Is Not Enough, the Remutualization of Clearinghouses, 34 YALE J. REG. 601 (2017) [hereinafter Saguato, The Ownership of Clearinghouses]. Additionally, an upcoming companion piece analyzes the current economic and governance structure of clearinghouses through a politico-economic lens and ultimately argues that the structure of clearinghouses is problematic and elaborate. See Paolo Saguato, Financial Regulation, Corporate Governance, and the Hidden Costs of Clearinghouses, 82 OHIO ST. L.J. (forthcoming 2021) [hereinafter Saguato, The Hidden Costs of Clearinghouses].

9 See, e.g., Michael Greenberger, Diversifying Clearinghouse Ownership in Order to Safeguard Free and Open Access to the Derivatives Clearing Market, 18 FordHAM J. CORP. \& Fin. L. 245 (2013); Sean J. Griffith, Governing Systemic Risk: Towards a Governance Structure for Derivatives Clearinghouses, 61 EMORY L.J. 1153 (2012); Yuliya Guseva, Destructive 
the structural fragilities inherent in clearinghouse organization could undermine the stability of financial markets and be the catalyst of the next financial crisis.

The current regulatory landscape of financial markets has its foundation in the dramatic events of the 2008 financial crisis and the structural reforms implemented by lawmakers in its immediate aftermath. ${ }^{10}$ The derivatives markets, ${ }^{11}$ vividly

Collectivism: Dodd-Frank Coordination and Clearinghouses, 37 CARDOZO L. REV. 1693 (2016); Kristin N. Johnson, Clearinghouse Governance: Moving Beyond Cosmetic Reform, 77 BRooK. L. REV. 681 (2012) [hereinafter Johnson, Clearinghouse Governance]; Kristin N. Johnson, Governing Financial Markets: Regulating Conflicts, 88 WASH. L. REV. 185 (2013) [hereinafter Johnson, Governing Financial Markets]; Adam J. Levitin, Response: The Tenuous Case for Derivatives Clearinghouses, 101 GEO. L.J. 445 (2013); Stephen J. Lubben, Failure of the Clearinghouse: Dodd-Frank's Fatal Flaw?, 10 VA. L. \& Bus. REV. 127 (2015) [hereinafter Lubben, Failure of the Clearinghouse]; Stephen J. Lubben, Always Crashing in the Same Car-Clearinghouse Rescue in the United Stated under Dodd-Frank, 3 J. FIN. REG. 133 (2017) [hereinafter Lubben, Always Crashing in the Same Car]; Jeffrey Manns, Insuring Against a Derivative Disaster: The Case for Decentralized Risk Management, 98 IowA L. REV. 1575 (2013); Hester Peirce, Derivatives Clearinghouses: Clearing the Way to Failure, 64 Clev. ST. L. REV. 589 (2016); Craig Pirrong, The Economics of Clearing in Derivatives Markets: Netting, Asymmetric Information, and the Sharing of Default Risks Through a Central Counterparty (Jan. 8, 2009) (unpublished manuscript), http://ssrn.com/abstract=1340660 [https://perma.cc/D94Y-RZ4E]; Craig Pirrong, The Economics of Central Clearing: Theory and Practice (Int'l Swaps \& Derivatives Ass'n Discussion Papers Series, Paper No. 1, 2011), https://www.isda.org/a/yiEDE/isdadiscussion-ccp-pirrong.pdf [https://perma.cc/F85S-FHDJ]; Mark J. Roe, Clearinghouse Overconfidence, 101 CALIF. L. REV. 1641 (2013); Richard Squire, Clearinghouses as Liquidity Partitioning, 99 CoRnell L. Rev. 857 (2014); Yesha Yadav, The Problematic Case of Clearinghouses in Complex Markets, 101 GEO. L.J. 387 (2013).

10 See Dodd-Frank Wall Street Reform and Consumer Protection (Dodd-Frank) Act, Pub. L. No. 111-203, 124 Stat. 1376 (2010) (codified as amended in scattered sections of 7, 12, and 15 U.S.C.). For the equivalent regulation in the European Union, see Council Regulation 648/2012, 2012 O.J. (L 201) 1.

11 Derivatives are financial transactions valued based on asset prices or other market variables. Derivatives allow two contractual parties to transfer the risk connected to an underlying asset. See, e.g., Alan N. Rechtschaffen, Capital Markets, Derivatives and the Law: Evolution AfTer CRISIS 51 (2d ed. 2014); Colleen M. Baker, Regulating the Invisible: The Case of Over-The-Counter Derivatives, 85 Notre Dame L. REV. 1287, 
portrayed in Michael Lewis's book The Big Short, ${ }^{12}$ were singled out as one of the catalysts of the crisis and underwent a radical makeover. ${ }^{13}$ Lawmakers agreed to centralize the risks of the derivatives markets in clearinghouses and trusted them to stabilize their fragile market structure. ${ }^{14}$

Clearinghouses have been the building blocks of modern financial markets for the past two centuries. ${ }^{15}$ They are the essential plumbing of the financial system, allowing capital to flow, securities to be transferred, and derivatives to be concluded. The largest securities and derivatives exchanges ${ }^{16}$

1299 (2010) (defining derivatives as "complex financial contracts in which one party pays another party if 'something' happens in the future"). See also Lynn A. Stout, Derivatives and the Legal Origin of the 2008 Credit Crisis, 1 HARV. Bus. L. REv. 1 (2011); Lynn A. Stout, Why the Law Hates Speculators: Regulation and Private Ordering in the Market for OTC Derivatives, 48 Duke L.J. 701 (1999); Henry T.C. Hu, Misunderstood Derivatives: The Causes of Informational Failure and the Promise of Regulatory Incrementalism, 102 Yale L.J. 1457, 1466 (1993); Dan Awrey, Split Derivatives: Inside the World's Most Misunderstood Contract, 36 YALE J. REG. 495 (2019) (providing a descriptive account of the legal and economic structure of derivatives). Derivatives markets play a central role in the American economic engine by supporting price stability and transactional efficiency. See J. Christopher Giancarlo \& Bruce Tuckman, Swaps Regulation Version 2.0: An Assessment of the CurRent Implementation of Reform and ProPOSALS FOR NEXT STEPS 1-2 (2018), https:/www.cftc.gov/sites/default/files/2018-04/oce_chairman_swapregversion2whitepaper_042618.pdf [https://perma.cc/SJ7P-JT65].

12 Michael Lewis, The Big Short: Inside the Doomsday Machine (2010); see also The Big SHORT (Paramount Pictures 2015).

13 See, e.g., David Skeel, The New Financial Deal: Understanding The DodD-Frank ACT AND Its (UnInTEnded) Consequences 59-75 (2011).

14 See Wall Street Transparency and Accountability Act of 2010, Pub. L. No. 111-203, §§ 701, 711-54, 761-74, 124 Stat. 1376, 1641-1802 (2010) (mandating the centralized trading, clearing, and reporting of financial derivatives).

15 See generally Ruben Lee, Running the World's Markets: The GovERnance of Financial Infrastructure (2011); Peter Norman, The Risk Controllers: CENTRAL Counterparty Clearing in Globalised Financial MARKETS (2011).

16 See Guido Ferrarini \& Paolo Saguato, Governance and Organization of Trading Venues: The Role of Financial Market Infrastructures Groups, in Regulation of the EU Financial Markets: MiFID II AND MiFIR 285, 298 307 (Danny Busch \& Guido Ferrarini eds., 2017) (discussing the structure 
including the New York Stock Exchange, the Chicago Mercantile Exchange, Nasdaq, and the Intercontinental Exchangerely on clearinghouses to process and settle several trillion dollars' worth of transactions daily. ${ }^{17}$

Clearinghouses operate as middlemen. ${ }^{18}$ They are intermediaries between buyers and sellers in the securities and derivatives markets. ${ }^{19}$ They serve as central counterparties: a clearinghouse breaks a derivative contract into two new ones, interposes itself between the two contractual parties in a trade, and assumes their respective positions. Clearinghouses, in effect, act as the buyer to every seller and as the

of six financial market infrastructural groups and the connection between trading platforms and exchanges and clearinghouses).

17 See NYSE American Options, N.Y. STOck Exchange, https://www.nyse.com/markets/american-options [https://perma.cc/K88JVW9L] (last visited May 23, 2020); Options on Futures, CME GrouP, https://www.cmegroup.com/trading/options.html [https://perma.cc/CKT2CAUZ] (last visited May 23, 2020); Futures Market Data \& News, NASDAQ, https://www.nasdaq.com/market-activity/futures [https://perma.cc/NMK2SYWZ] (last visited May 23, 2020); About, InTERCONTINENTAL EXCHANGE, https://www.theice.com/about [https://perma.cc/KNF3-YZFD] (last visited May 11, 2020). As of December 2019, the total notional amount of outstanding over-the-counter ("OTC") financial derivatives was nearly $\$ 559$ trillion. See Global OTC Derivatives Market, BANK For InT'L SETTLEMENTS (2019), https://stats.bis.org/statx/srs/table/d5.1?p=20192\&c=

[https://perma.cc/Z3AE-MN7A]. Additionally, more than $60 \%$ of the total outstanding OTC derivatives were centrally cleared though a clearinghouse. See id. But see Felix B. Chang, Second-Generation Monopolization: Parallel Exclusion in Derivatives Markets, 2016 Colum. Bus. L. Rev. 657, 689 (2016) (pointing at the difficulties in calculating the exact size of the derivatives market, and the potential imprecision of the Bank for International Settlement's statistic due to double-counting).

18 Clearinghouses in modern financial markets primarily operate with a central counterparty ("CCP") model, which directly assumes the ultimate costs of the cleared transactions. For this reason, academic literature and the media refer interchangeably to clearing firms as "clearinghouses" or as "CCPs." See infra Section II.A (discussing the economics and functions of clearinghouses).

19 This Article primarily focuses on derivatives clearinghouses. For a discussion of how derivatives clearinghouses differ organizationally from securities clearinghouses, see Saguato, The Ownership of Clearinghouses, supra note 8 , at $632-33$. 
seller to every buyer. ${ }^{20}$ By acting as central counterparties, ${ }^{21}$ clearinghouses take on and bear the risks of the cleared transactions and agree to guarantee that each party be made whole, even in the event of the default of the other. Should either party default, the clearinghouse prevents the fallout from spilling over into the markets. ${ }^{22}$

Clearinghouses provide this essential and critical risk internalization function by having in place a unique guaranty scheme whose features and risk allocation mechanisms often go overlooked. ${ }^{23}$ While clearinghouses formally assume the risk of the transactions that they process, they actually externalize the ultimate risk of failure by passing down the costs of counterparty defaults to their members-large financial institutions that were mandated by the Dodd-Frank Wall Street Reform and Consumer Protection Act ("Dodd-Frank" or "the Dodd-Frank Act") to use clearinghouses' services to process derivatives transactions. ${ }^{24}$ When a financial firm is admitted as a clearing member, it agrees and becomes contractually bound to the clearinghouse's rulebooks. ${ }^{25}$ This means that

20 See Comm. on Payments \& Settlement Sys., Bank for InT'L SettleMENTS, RECOMMENDATIONS FOR CENTRAL COUNTERPARTIES 5 (2004).

21 Clearinghouses do not provide a trading function; rather, they only operate in the post-trading phase of a deal once the contracting parties have agreed on the terms.

22 See Philip Stafford, How Clearing Houses Aim to Avert Market Disasters, Fin. TIMES (Sept. 14, 2018), https://www.ft.com/content/01596fdeb805-11e8-b3ef-799c8613f4a1 [https://perma.cc/URZ6-LXY5].

23 See infra notes 82-99 and accompanying text (discussing in depth the mechanism of the default guaranty fund, the "guaranty program" of clearinghouses).

24 See Dodd-Frank Act, Pub. L. No. 111-203, § 723, 124 Stat. 1376, 1675 (2010) (codified as amended at 7 U.S.C. $\$ 2$ (2018)).

25 See e.g., Chi. Mercantile Exch., CME Rulebook $§ 101$ [hereinafter CME RULES], https://www.cmegroup.com/content/dam/cmegroup/rulebook/CME/I/1/1.pdf [https://perma.cc/VT2C-W9AZ]; Membership, CME GROUP, https://www.cmegroup.com/company/membership.html?redirect=/company/membership/files/Summary-of-CMEG-Clearing-Membership-Requirements.pdf [https://perma.cc/S5YQ-GY3M] (last visited May 25, 2020); ICE Clear U.S., Clearing Membership Information Package 2, https://www.theice.com/publicdocs/clear_us/Clear_US_Clearing_Membership_Information_Package.pdf [https://perma.cc/NVJ7-6EE6]; ICE CLEAR Credit, Clearing Rules 26-36 (2020) [hereinafter ICE Clear Credit, 
clearinghouse members agree to contribute to a mutual guaranty fund that can be used to cover any risk associated with the failure of a peer member. ${ }^{26}$ This is the peculiar feature of the clearinghouses' business model that makes them unconventional corporations.

In a traditional corporation, the firm's assets are used to cover its liabilities. As the residual claimants of the venture, ${ }^{27}$ the firm's shareholders-while receiving control rights over the business and participating in the firm's earnings-bear the final risk, and absorb the firm's losses up to the amount of their investment. ${ }^{28}$ In the traditional corporate context, however, the firm's customers and users are not required to financially contribute to the firm's viability if it were to run into financial trouble.

The modern clearinghouse reverses this traditional corporate paradigm: the role of the firm's primary stakeholdersits shareholders and members-is inverted. ${ }^{29}$ The clearing members that access the services of a clearinghouse ${ }^{30}$ bear

CLEARING RULES], https://www.theice.com/publicdocs/clear_credit/ICE_Clear_Credit_Rules.pdf [https://perma.cc/RD2T23ER]. Clearinghouses, or more specifically, Derivatives Clearing Organizations ("DCOs") and Clearing Agencies ("CAs"), have been identified respectively by the CFTC and the SEC as Self-Regulatory Organizations, a designation that empowers them to set, within the regulatory perimeters of the competent regulatory agency, their own internal governance and operational rules. See infra Section IV.B; see also Roberta S. Karmel, Should Securities Industry Self-Regulatory Organizations Be Considered Government Agencies?, 14 STAN. J.L. Bus. \& FIn. 151 (2008).

26 When members are admitted to a clearinghouse, they agree to offer collateral as a guaranty-margin - for the open positions they have with the firm. In addition, they all agree to contribute to a pool of resources aimed at absorbing and sharing the costs associated with the default of any other member. See infra notes 82-99 and accompanying text.

27 See, e.g., Reinier KraAkman et AL., The Anatomy of Corporate LAW: A COMPARATIVE AND FunCTIONAL APPROACH 23 (3d ed. 2017).

28 See William A. Klein et AL., Business Organization and Finance 123 (11th ed. 2010).

29 For an in-depth discussion of the "member-shareholder divide" see Saguato, The Ownership of Clearinghouses, supra note 8, at 640-48. See also infra Section III.

30 After the implementation of the Dodd-Frank Act, many classes of derivatives were required by law to be centrally cleared. Consequently, the 
and mutually share the potential residual losses of the clearing business because of their contributions to the guaranty fund. ${ }^{31}$ However, this role is not coupled with any formal control right over the governance of the firm. ${ }^{32}$ On the other hand, the clearinghouse's shareholders are peculiar residual claimants. ${ }^{33}$ The shareholders receive the earnings of the business and have control rights over it, but they are substantially shielded from any risk of loss by the financial resources provided by the members of the clearinghouse. ${ }^{34}$

This unique economic and governance structure creates what I define as the "member-shareholder divide." 35 The tension between clearinghouses' primary stakeholders-members and shareholders-spills from the "separation of risk and control" 36 and creates misaligned incentives and unique

use of clearinghouses became mandatory. See Dodd-Frank Act, Pub. L. No. 111-203, § 723, 124 Stat. 1376, 1675 (2010).

31 See infra Section II.A.

32 See infra Section II.B.

33 See Saguato, The Ownership of Clearinghouses, supra note 8, at 642. Clearinghouses are closed corporations, generally wholly owned subsidiaries of large public financial holding companies. Clearinghouses are part of large financial market infrastructural groups. See Ferrarini \& Saguato, supra note 16, at 305-06. In some instances, clearinghouses are independent subsidiary corporations. See, e.g., ICE Clear Credit, Disclosure FrameWORK 3 (2020), https://www.theice.com/publicdocs/clear_credit/ICEClearCredit_DisclosureFramework.pdf [https://perma.cc/K4W9-S5BK]. Sometimes, they are simply business units of a corporation. See CME Clearing Membership, CME Group, https://www.cmegroup.com/company/membership/clearing/cme.html [https://perma.cc/FKK6-F6G7] (last visited May 24, 2020).

34 See infra Section II.A.

35 See Saguato, The Ownership of Clearinghouses, supra note 8, at 640-48.

36 The concept of the "separation of risk and control" is modeled on the famous corporate law and economics concept of "separation of ownership and control," which characterizes modern public corporations. See ADOLF A. Berle \& Gardiner C. Means, The Modern Corporation and Private PropERTY 5-6 (Harcourt, Brace \& World, Inc. 1968) (1932); Eugene F. Fama \& Michael C. Jensen, Separation of Ownership and Control, 26 J.L. \& Econ. 301 (1983). For a more in depth discussion of the agency costs associated with the separation of risk and control, see Saguato, The Hidden Costs of Clearinghouses, supra note 8 (manuscript at 25-32). 
agency costs between the residual risk bearers (the clearing members) and the risk takers (the clearing firm and its controlling shareholders). ${ }^{37}$ These conflicts can increase the clearinghouse's moral hazard and potentially undermine its financial resilience. ${ }^{38}$

This Article builds on the theoretical frameworks developed in my previous works on the ownership, ${ }^{39}$ governance, and capital structure ${ }^{40}$ of clearinghouses. It explores how the existing public regulatory framework and private self-regulatory regime deal with the unique agency costs and misaligned incentives faced by clearing firms and their primary stakeholders. The Article looks at clearinghouses from a microprudential perspective, i.e., as standalone financial institutions, ${ }^{41}$ and shows how the existing approach to clearinghouses and their regulation falls short in addressing the moral hazard that stems from the separation of risk and control and might actually exacerbate the agency costs between members and shareholders.

37 See, e.g., Henry Hansmann \& Reinier Kraakman, The Essential Role of Organizational Law, 110 YALE L.J. 387, 393 (2000); Michael C. Jensen \& William H. Meckling, Theory of the Firm: Managerial Behavior, Agency Costs and Ownership Structure, 3 J. FIN. ECON. 305 (1976) (developing a formal analysis of agency costs).

38 On the general problem of moral hazard, see Jensen \& Meckling, supra note 37, at 309-10; GeOfFrey Miller, Trust, RIsK, AND MoRAL HAZARD IN FINANCIAL MARKETS 73-88 (2011) (defining moral hazard as the situation where an actor loses some of her incentives to take precautions to prevent harm because she transfers the risks and costs of the harm to a third party). See also infra Part II (analyzing the unique economic and governance structure of clearinghouses).

39 See Saguato, The Ownership of Clearinghouses, supra note 8 (providing the first in-depth analysis of the history and implications of different clearinghouse ownership structures). This Article complements the previous piece by analyzing what it left off the table-namely, the corporate governance of these firms, their capital regulation, and their recovery and resolution mechanisms.

40 See Saguato, The Hidden Costs of Clearinghouses, supra note 8.

41 It is outside the scope of this Article to look into the macroprudential considerations and dynamics of clearinghouses, i.e., the role, functions, effects, tradeoffs, and consequences that clearinghouses have as an integral part of the financial system. 
Building on the existing literature on the corporate governance of financial institutions ${ }^{42}$ and on systemic risk and capital regulation, ${ }^{43}$ this Article fills a critical gap in the academic debate on financial market infrastructures ("FMIs") and contributes to a better-informed policy dialogue on the regulation of clearinghouses. The Article makes three main contributions. First, effective risk management in clearinghouses can be achieved only if the final risk bearers have a voice in the governance of the firm. Second, capital requirements that operate countercyclically are essential in order to create systemic resilience in financial institutions. Third, clear and certain recovery plans are an essential component of avoiding financial panic and achieving effective crisis management. The refined and concrete policy recommendations advanced by the Article regarding how to retune some provisions of the Dodd-Frank Act and address the serious and still-unsolved issues in the governance, accountability, and financial resilience of clearinghouse ${ }^{44}$ intend to advance, and modestly complete, the regulatory journey begun by the Dodd-Frank Act in 2010.

42 See, e.g., Jonathan R. Macey \& Maureen O'Hara, The Corporate Governance of Banks, 9 ECON. POL'Y REV. 91 (2003); Jonathan Macey \& Maureen O'Hara, Bank Corporate Governance: A Proposal for the Post-Crisis World, 22 Econ. Pol'y Rev. 85 (2016); Anat Admati \& Martin Hellwig, The BankERS' NEW Clothes: What's WrONG WITH BANKING AND WHAT TO DO ABOUT IT (2013); David Min, Balancing the Governance of Financial Institutions, 40 SEattle U. L. REV. 743 (2017); Guido Ferrarini, Understanding the Role of Corporate Governance in Financial Institutions: A Research Agenda (Eur. Corp. Governance Inst., Working Paper No. 347, 2017), https://ssrn.com/abstract=2925721 [https://perma.cc/UP2R-QP5V].

43 See Steven L. Schwarcz, Systemic Risk, 97 GEO. L.J. 193, 204 (2008) (defining systemic risk as "the risk that (i) an economic shock such as market or institutional failure triggers . . . either (X) the failure of a chain of markets or institutions or $(\mathrm{Y})$ a chain of significant losses to financial institutions, (ii) resulting in increases in the cost of capital or decreases in its availability, often evidenced by substantial financial-market price volatility").

44 Some academic work overlooks the importance and implications of the organizational structure of clearinghouses as a potential source of systemic instability. See Roe, supra note 9; Levitin, supra note 9; Peirce, supra note 9; Yadav, supra note 9. 
This Article is structured as follows. Part II analyzes the economic and organizational structure of clearinghouses. Part III identifies the unique agency costs originating from the separation of risk and control and places clearinghouses in the broader context of corporate and financial law. Part IV examines the existing regulatory framework built by the DoddFrank Act and argues that it created a flawed governance and capital regime that threatens clearinghouses' systemic resilience. Part V tackles the unsolved issues in the regulation of clearinghouses' resilience, recovery, and resolution. This Part offers concrete policy recommendations regarding how to improve clearinghouses' governance and economic structure and create a more systemically sound infrastructure. This Article concludes that the clearing market is ripe for reform, and that lawmakers and regulators should consider novel approaches to address the agency costs that clearinghouses currently face.

\section{CLEARINGHOUSES: ECONOMICS AND ORGANIZATION}

Clearinghouses are the plumbing of the financial markets. Because they operate behind the scenes, they are often overlooked. This Part brings the function of clearinghouses to light, explaining their critical role in supporting efficient and stable financial markets. It then discusses how clearinghouses are organized as firms and how they operate in financial market environment.

\section{A. The Economics of Central Clearing: What Clearinghouses Do}

Clearinghouses are the product of synergies among market participants that create a mechanism to centralize, pool, manage, and ultimately share the risks and losses of transacting in financial contracts. ${ }^{45}$ Widely used in the securities,

45 See Saguato, The Ownership of Clearinghouses, supra note 8, at 614-23. See also Norman, supra note 15, at 51-66 (offering a brief historical account of the evolution of trading and post-trading practices, with a narrow focus on clearinghouses). 
commodities, and derivatives markets, ${ }^{46}$ clearinghouses intervene after a trade is executed between two parties and support the post-trading phase of the transaction. ${ }^{47}$ They confirm and reconcile the contractual terms, administer and manage the provision of contractual guarantees-collateral-and ensure the performance of the contract. ${ }^{48}$ To effectively manage risk and compress exposure, clearinghouses generally act as central counterparties ("CCPs") for a group of dealer firms-the members of the clearinghouse that apply for membership status to access clearing services and pay fees to have their trades cleared. Through a process of novation, ${ }^{49}$ the clearinghouse breaks the original contract into two new contracts and interposes itself between the original parties, becoming the buyer to the original seller and the new seller to the original buyer. After the contract is novated, the clearinghouse has two opposite, matching, and offsetting positions on its balance sheet and operates with a "matched book," meaning that each claim that the clearinghouse has against one of its members (i.e., asset) is matched by a claim against the clearinghouse (i.e., liability). ${ }^{50}$ Operating with a matched book means that the clearinghouse is primarily exposed to the risk of the failure of its members (i.e., counterparty credit risk) and is not directly exposed to market risk. ${ }^{51}$ In normal times, market fluctuations create no net change in the firm's liquidity and balance sheet. ${ }^{22}$ Because of its matched book, if for instance the short exposure of a clearinghouse in a specific transaction

46 See Paolo Saguato, The Liquidity Dilemma and the Repo Market: A Two-Step Policy Option to Address the Regulatory Void, 22 STAN. J.L. Bus. \& FIN. 85 (2017) (identifying the potential benefits of expanding clearing via central clearing counterparties to the repurchase agreements markets as a mechanism to reduce risk).

47 See Saguato, The Ownership of Clearinghouses, supra note 8, at 614 .

48 Id. at $614-16$.

49 Novation is a legal process whereby an original obligation or party is substituted with a new one. See Jon Gregory, Central Counterparties: Mandatory Clearing and Bilateral Margin Requirements For OTC DERIVATIVES 28 (2014).

50 See Squire, supra note 9 , at 859.

51 See Saguato, The Ownership of Clearinghouses, supra note 8, at 615.

52 See GREGORY, supra note 49, at 29. 
increases, then its corresponding long position in the same transaction increases. This means that if, because of market fluctuation, the clearinghouse were to owe more to an original buyer, then that increase in exposure on the clearinghouse liability side would be matched by an increase in the amount owed to the clearinghouse by the original seller, creating a corresponding increase in the clearinghouse's asset side.

As an illustration of how a clearinghouse operates, imagine that A wishes to sell to B a Bitcoin future ${ }^{53}$ - that is, a financial derivative where the seller agrees to deliver, at a specified date, a specified asset to the buyer, who agrees to pay a specified price. ${ }^{54} \mathrm{~A}$ can deal directly with $\mathrm{B}$ and negotiate, conclude, and clear a bilateral contract. ${ }^{55}$ Each party will assume the costs and risks associated with dealing directly with its own counterparty, including the risk of either's default. The parties can offset these risks by requiring the posting of collateral, periodically assessing the risk underlying the transaction, and consequently readjusting their respective positions. ${ }^{56}$ On the other hand, the parties can decide to access the services of market infrastructures. ${ }^{57}$ They can have their buy

53 Starting in December 2017, the largest trading and clearing platforms in the U.S. have started offering futures contracts for Bitcoin. See Bitcoin Futures and Options on Futures, CME GROUP, https://www.cmegroup.com/trading/bitcoin-futures.html [https://perma.cc/NJ8Q-YE88] (last visited May 30, 2020); Fully Regulated End-to-End: Bakkt Bitcoin Futures \& Options, BAKKT, https://www.bakkt.com/bakkt-markets\#derivatives [https://perma.cc/DT5L-G87G] (last visited May 15, 2020). Futures contracts allow parties to hedge against fluctuations in asset prices and investors to place long and short-term positions in cryptocurrency markets. See Introduction To Futures-Definition of a Futures Contract, CME GROUP, https://www.cmegroup.com/education/courses/introduction-to-futures/definition-of-a-futures-contract.html [https://perma.cc/2QVW-W4EY] (last visited July 1, 2020).

54 This example is modeled on Squire, supra note 9, at 862-69 (describing the structure of a cleared derivative transaction).

55 See David Murphy, OTC Derivatives: Bilateral Trading ANd CENTRAL CLEARING 9-20 (2013) (analyzing the structure of trading and clearing in bilateral markets and the risks therein).

56 See Saguato, The Ownership of Clearinghouses, supra note 8, at 618.

57 See Guido Ferrarini \& Paolo Saguato, Regulating Financial Market Infrastructures, in The OxFord HandBook of Financial REgUlation 568 
and sell orders processed by a trading venue, and, after they agree on the price, quantity, and maturity of the contract and the contract is executed by the platform, they can have the contract cleared by the clearinghouse-in this case, CME Clearing. ${ }^{58} \mathrm{CME}$ Clearing would interpose itself between parties A and B, acting as the CCP and taking on the ultimate performance of the contract. Thus, instead of having A as a contractual party in the Bitcoin future, B will deal directly with CME clearing. ${ }^{59}$

In acting as CCPs, clearinghouses have been designed to support the efficient, safe, and sound operation of financial markets. ${ }^{60}$ From a microeconomic perspective, they convey transactional and operational benefits by mitigating counterparty risk and by optimizing the use of capital. ${ }^{61}$ From a macroeconomic angle, they provide systemic support to the markets by contributing to market liquidity and by mutualizing the counterparty default risk among a select group of financial institutions that access their clearing services. ${ }^{62}$ They do so by collecting pre-funded resources that can be deployed to cover the losses caused by the failure of one or more of those institutions. ${ }^{63}$

While post-trading services, and clearinghouses in particular, have often been overlooked by the academic literaturewhich is more focused on the trading ecosystem and its

(Niamh Moloney et al. eds., 2015) (analyzing the critical role financial market infrastructure plays in modern financial markets).

58 See Chi. Mercantile Exch., An Introduction to Futures and Op. TIONS 7 (2006), http://www.cmegroup.com/files/intro_fut_opt.pdf [https://perma.cc/XK7Q-PL86] (describing trading and post-trading services at the Chicago Mercantile Exchange Group).

59 See id. at 7.

60 See generally NORMAN, supra note 15 (offering a comprehensive and incise discussion on the historical evolution of CCPs and the critical role they play as risk controllers in globalized financial markets); TINA P. HASENPUsch, Clearing Services for Global Markets 41-49 (2009).

61 See infra notes 70-77 and accompanying text (discussing the critical role multilateral netting plays to reduce counterparty exposures, collateral requirements, etc.).

62 See Saguato, The Ownership of Clearinghouses, supra note 8, at 615; see also HASENPUSCH, supra note 60, at 44-49.

63 See infra Section II.B. 
microstructure ${ }^{64}$ - they are still essential for the functioning of financial markets. Clearinghouses contribute to the efficiency and stability of financial markets by freeing up capital, supporting trade finalization certainty, and injecting confidence in the stability of the overall securities and derivatives trading market environment. ${ }^{65}$

A clearinghouse's toolkit is composed of three primary elements: ${ }^{66}$ (i) multilateral or multiparty netting;67 (ii) specialized risk management processes and mechanisms; and (iii) (prefunded) loss-absorbing (and mutualization) resources. ${ }^{68}$ The

64 See generally Maureen O'Hara, Market Microstructure Theory (1995); Merritt B. Fox et Al., The New Stock Market: LaW, Economics, AND POLICY (2019).

65 See Saguato, The Ownership of Clearinghouses, supra note 8, at 630-32. Clearinghouses also operate in repurchase agreement markets where they contribute to the stability of transactions and have supported the orderly process of trading. See Saguato, supra note 46 (analyzing the role central clearing could play in repo markets); Steven L. Schwarcz, Central Clearing of Financial Contracts: Theory and Regulatory Implications, 167 U. PA. L. REV. 1327, 1347-56 (2019) (exploring the feasibility of expanding central clearing to nonderivative financial contracts such as loan agreements).

66 Some scholars identify these three risk management mechanisms as loss distribution forms. Multilateral netting and margin requirements are defined as loss externalization tools as they pass the costs of failure of a clearing member onto clearinghouses' outside creditors. See Squire, supra note 9, at 863-71. On the other hand, loss mutualization tools include the guaranty fund, the pool of resources provided by all members, which spreads the cost of one member's default among all non-defaulted members. See Squire, supra note 9, at 871-72. As discussed in the next Section, loss mutualization mechanisms are also loss externalization tools in practice. See infra Section II.B. From the perspective of clearinghouses and their shareholders, all the above-mentioned mechanisms pass the costs of default down on to third parties-precisely those parties who are not in privity of contract with the defaulted party.

67 Netting is the process of compressing reciprocal and opposite positions. See Paolo Saguato, Unbundling Complexity: The Law and Economics on Netting 16-20 (May 2020) (unpublished manuscript) (on file with author).

68 Two additional functions performed indirectly by clearinghouses are transparency enhancement (by reporting the data of cleared transactions), and contract standardization (as a basic prerequisite to operating of a "matched book"). 
first two features are made possible by the novation process and operate primarily as microprudential transactional tools to mitigate counterparty risk. The third feature, which is the ultimate risk management mechanism to contain counterparty risk, contributes to the macroprudential mission of mitigating systemic risk and reducing complexity in the financial system. ${ }^{69}$

By operating as CCPs, clearinghouses become the central nodes of a multitude of trades. Their role as buyers to every seller and sellers to every buyer allows them to compress and offset opposite positions through a process of multilateral netting. ${ }^{70}$ Expanding upon the previous example, imagine that $\mathrm{A}$ has sold a Bitcoin future to $\mathrm{B}^{71}$ and has bought one from $\mathrm{C},{ }^{72}$ and imagine that $\mathrm{C}$ bought another Bitcoin future from B. Assume that the futures have to be cash-settled ${ }^{73}$ and imagine

69 As further developed in this Section, clearinghouses do not fully eliminate financial risk and complexity from the financial market. See infra notes 71-77 and accompanying text. However, by novating contracts and becoming a central counterparty for a multitude of trades, clearinghouses remove the risk from bilateral transactions among dealers and centralize it within their own walls. That is, financial risk is not eliminated from the system, but it is centralized, mitigated, and managed by specialized risk managers. See infra notes 78-83 and accompanying text.

70 See Saguato, The Ownership of Clearinghouses, supra note 8, at 616-18.

71 The seller of a futures contract, the party "going short" on the futures, takes on the obligation to provide and deliver the underlying asset when the contract comes to maturity. See CHI. Mercantile ExCH., supra note 58 , at 37 .

72 The buyer of a futures contract, the party "going long" on the futures, assumes the obligation to buy and receive the underlying asset when the contract comes to maturity. Id. at 36,38 .

73 Cash settlement is one way a futures contract can be performed. In a cash settlement, the parties to the contract agree to exchange a sum of money equal to the difference between the price at the time the contract was entered into and the price at the time the asset delivery is scheduled to be performed. No physical delivery of the asset is required to perform the contract. $I d$. at 38 ("Cash settlement, in futures trading, simply means the offsetting of an outstanding futures obligation with a final mark-to-market adjustment. The trader will ultimately receive (or pay) the difference between the price at which the trader initiated the position, and the final settlement price."). 
that the price of Bitcoin has sharply risen so that, as of today, A would owe B $\$ 100$, B would owe C $\$ 200$, and C would owe A $\$ 200$. Without multilateral netting, the overall exposure in this three-party market would be $\$ 500$.

Figure 1: Multilateral transactions without a clearinghouse

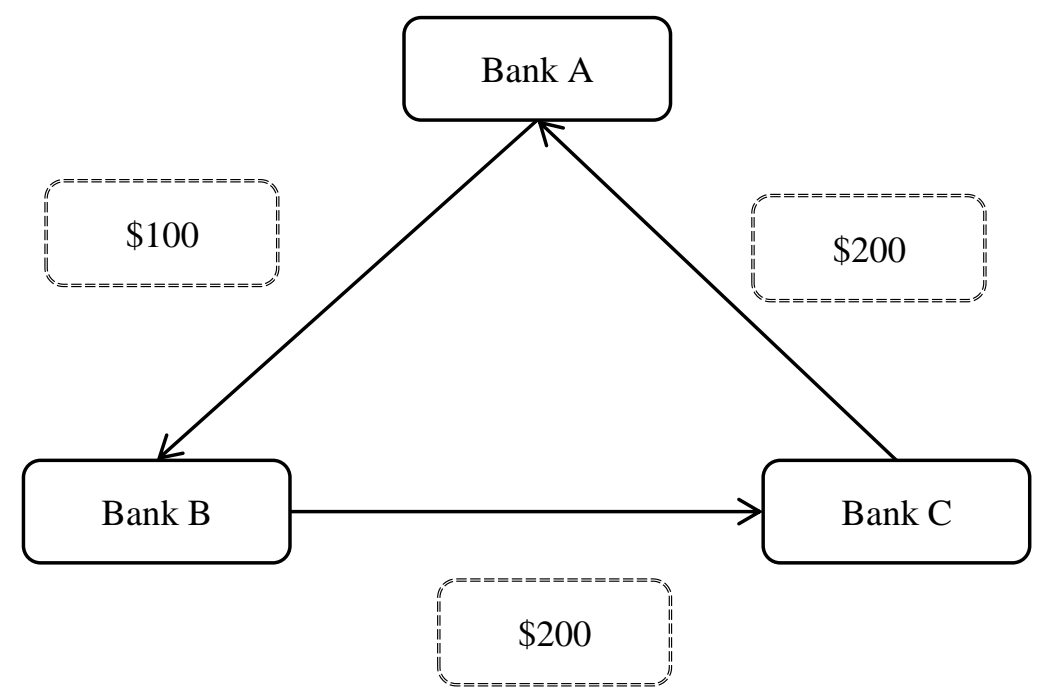

Now imagine that $\mathrm{A}, \mathrm{B}$, and $\mathrm{C}$ are members of a clearinghouse and as such have their contracts centrally cleared. As a result, the original contracts between $\mathrm{A}$ and $\mathrm{B}, \mathrm{B}$ and $\mathrm{C}$, and $\mathrm{A}$ and $\mathrm{C}$ will novate and the clearinghouse will become the sole counterparty for A, B, and C. In addition, by virtue of multilateral netting, the original parties will be able to reduce their overall counterparty risk exposure from multiple open positions to a new "netted" one with the clearinghouse. ${ }^{74}$ The overall exposure in the cleared market would drop from $\$ 500$ to $\$ 200$. C would be able to completely set off its mutual and

74 This is a simplification of the operation of netting in a centrally cleared environment. Multilateral netting generally does not operate across all asset classes of centrally cleared transactions but is generally applied to a standardized set of cleared contracts. See Saguato, supra note 67 (manuscript at 18). 
reciprocal obligations to the clearinghouse ( $\$ 200$ owed and $\$ 200$ owing), while A would be entitled to receive $\$ 100$ and $\mathrm{B}$ would owe the clearinghouse $\$ 100$. When executed on a rolling basis, multilateral netting eliminates offsetting positions, compresses the number of contractual obligations, and reduces the number of payment obligations and contractual guarantees to be pledged. Netting mitigates parties' exposure to counterparty default risk and optimizes the use of collateral, ${ }^{75}$ ultimately supporting market liquidity and a more efficient use of capital. Netting is not only executed to process open positions, but is also triggered when a contractual party defaults on its obligation. ${ }^{76}$ This type of netting is generally referred to as "close-out set-off netting" and expedites the liquidation of the positions of defaulting parties. ${ }^{77}$

75 Collateral is the guarantee a contractual party requests from its counterparty to mitigate its credit exposure. If a clearinghouse, through multilateral netting, reduces its counterparty risk, then it would be able to proportionately reduce the amount of collateral it requests to hedge against its counterparty default risk.

76 See Saguato, supra note 67 (manuscript at 13-14).

77 See Squire, supra note 9, at 899-902. For a different and more critical assessment of netting see Roe, supra note 9, at 1660-62. Bankruptcy law scholars have widely discussed the special regime the bankruptcy code reserves for a specific class of financial transaction. Those scholars also analyze the inherent costs and benefits these special bankruptcy code sections create for contractual parties and for the financial system as a whole. See e.g., Franklin R. Edwards \& Edward R. Morrison, Derivatives and the Bankruptcy Code: Why the Special Treatment?, 22 YALE J. REG. 91, 101 (2005). 


\section{Figure 2: Multilateral Transactions with a Clearing- house}

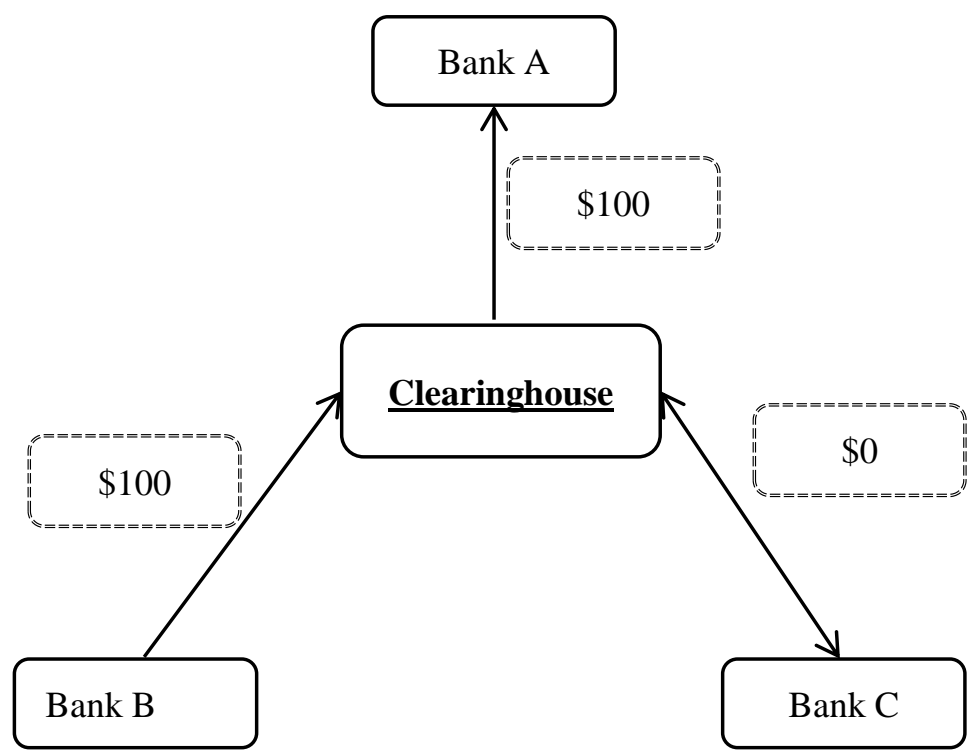

By becoming the transactional node for cleared markets and accessing information about all cleared transactions, a clearinghouse can more effectively and accurately assess, price, and monitor the risk in the serviced market. Clearinghouses thus become information intermediaries. ${ }^{78}$ They gather information about counterparties' overall exposure and have a comprehensive view of the types and distribution of the assets that are generally accepted as collateral. By accessing and processing this information, clearinghouses can operate as systemic risk managers, and more accurately price services for their members. Eventually, acting on this proprietary information, they can proactively adjust their risk profiles and tune their contractual positions to reflect and balance changes

78 See Paolo Saguato, The New Information Intermediaries (Jan. 2019) (unpublished manuscript) (on file with author) (analyzing the growing role and influence of clearinghouses as information intermediaries and discussing the implications of clearinghouses acting as part of a large financial infrastructural group heavily engaged in selling informational services and data to market participants). 
in financial markets. From the regulators' perspective, clearinghouses offer an effective stream of data on the derivatives markets. This was missing in the pre-crisis world.

Clearinghouses are systemic and specialized risk managers. ${ }^{79}$ Their core business is managing risk. In performing their mission, clearinghouses establish risk management practices to mitigate counterparty credit risk, 80 contain market risk, ${ }^{81}$ address operational risk, ${ }^{82}$ and prevent liquidity risk. ${ }^{83}$ Clearinghouses have a staggered arsenal of risk management requirements, processes, and practices they employ to support the financial resilience of the firm, ${ }^{84}$ along with multiple lines of defense to tackle risk.

The first line of defense that clearinghouses deploy is the membership requirements they impose on clearing members. Not all market participants can directly access clearing services; only qualified financial institutions are granted a license to access a firm's services. ${ }^{85}$ Clearinghouses retain strong powers over setting entry standards: they mandate stringent prudential, financial, and capital adequacy requirements to qualify as a clearing member. ${ }^{86}$ Once a financial

79 See generally NoRMAN, supra note 15, at 9-12 (defining clearinghouses as risk controllers).

80 Counterparty credit risk is the risk that a contractual counterparty will default on its obligations. See Comm. on Payments \& SetTlement Sys., Bank for InT'L SetTlements, Principles for Financial Market InFraSTRUCTURES 19 (2012).

81 Market risk is the risk associated with fluctuations in market prices, which affects the value of assets. See id.

82 Operational risk is the risk of losses resulting from deficiencies and breakdowns in internal processes, human errors, management failures, or general disruptions in the operation of the clearing business. See id. at 20 .

83 Liquidity risk is the risk that a counterparty, or the clearinghouse itself, will have insufficient liquid funds to meet its financial obligations. See id. at 19.

84 See Saguato, The Ownership of Clearinghouses, supra note 8, at 619-23.

85 See supra note 25 and accompanying text.

86 See, e.g., CME RULEs, supra note 25, § 101; ICE ClEAR CREDIT, Clearing Rules, supra note 25. 
institution is admitted as a member, ${ }^{87}$ clearinghouses have the right to inspect the member's books, and subject the member to ongoing financial disclosure and periodic monitoring of their internal risk management practices and policies. ${ }^{88}$ Clearinghouses retain the right to either suspend or withdraw membership privileges if the member falls short in complying with the prudential standards included in the clearinghouse's rule book. ${ }^{89}$ Furthermore, and critical to the smooth functioning of the firm, members agree to be bound by and comply with all of the conditions that come along with their status as members. ${ }^{90}$ In particular, once admitted as members, financial institutions are required to contribute to the financial resources that clearinghouses collect to support the business and, if one should occur, internalize the losses of the default of one or more of their members while mutualizing the losses across the non-defaulted ones. ${ }^{91}$ Participation in the risk mutualization mechanism is a necessary condition for admission as a clearinghouse member..$^{92}$

Beyond membership admission and the maintenance of members' status, members are contractually required to contribute to clearinghouses' financial resilience. Members must provide the clearinghouse with loss-absorbing resources that make it possible for it to operate as a systemic risk absorber. These financial resources, which are managed by the

87 The membership of derivatives clearinghouses is comprised of major global financial institutions. See Clearing Firms, CME Group, https://www.cmegroup.com/clearing/financial-and-regulatory-surveillance/clearing-firms.html\#clearingFirms [https://perma.cc/AG93-3LU5] (last visited Aug. 14, 2019); Ice Clear Credit: Participants, InTERCONTINENTAL EXCHANGE, https://www.theice.com/clear-credit/participants [https://perma.cc/HAP5-MZFA] (last visited Aug. 14, 2019).

88 See CME Rules, supra note 25, § 195; ICE ClEAR CREDIT, ClEARING RULES, supra note 25, at 43.

89 See CME RULES, supra note 25, §§ 130, 133; ICE ClEAR CREDIT, CleARING RULES, supra note 25, at 29.

90 See CME Rules, supra note 25, § 122; ICE Clear CREdit, Clearing RULES, supra note 25, at 29.

91 See CME Rules, supra note 25, § 816; ICE Clear CREdit, Clearing RULES, supra note 25, at 102-03.

92 See Saguato, The Ownership of Clearinghouses, supra note 8, at $618-23$. 
clearinghouse, serve as the two most substantial lines of defense to absorb risks and losses. These primary lines of defense are margin collateral and the default guaranty fund. ${ }^{93}$ By making these contributions, clearing members make it possible for the clearinghouse to position itself in the financial markets as a robust bastion of financial stability against crises. Together with the cushion of resources committed by the clearinghouse to support the firm in the orderly management of the default of its member(s), ${ }^{94}$ the amalgamation of the different layers of financial resources deployable by clearinghouses-and the order in which these lines of defense are positioned-is generally referred to as the "default waterfall" of recovery resources, ${ }^{95}$ and it varies from clearinghouse to clearinghouse. Figure 3 offers an example of the operation and order of the different lines of defense in a clearinghouse default waterfall. ${ }^{96}$

93 See id. at $620-21$.

${ }^{94}$ See id. at 620.

95 See Jessie Jiaxu Wang et al., A Theory of Collateral Requirements for Central Counterparties 8-10 (Feb. 29, 2020) (unpublished manuscript), https://ssrn.com/abstract=3290397 [https://perma.cc/8J2A-JMAH].

96 Figure 3 summarizes and simplifies the operations of the default waterfall in the recovery phase when a clearinghouse cannot rebalance its books by auctioning off the open positions of the defaulted member and needs to tap the pre-funded resources that it collects as solvency guarantees. The operation of the default waterfall and the recovery phase in general is based on the contractual agreement between the clearinghouse and its shareholders. See Darrell Duffie, Resolution of Failing Central Counterparties, in Making FAILURE FEASIBLE: How CAN BANKruptcy ReForm CAN END “Too Big To FaIL" 87, 90-92 (Kenneth E. Scott et al. eds., 2015). 
Figure 3: Model of a clearinghouse "default waterfall"

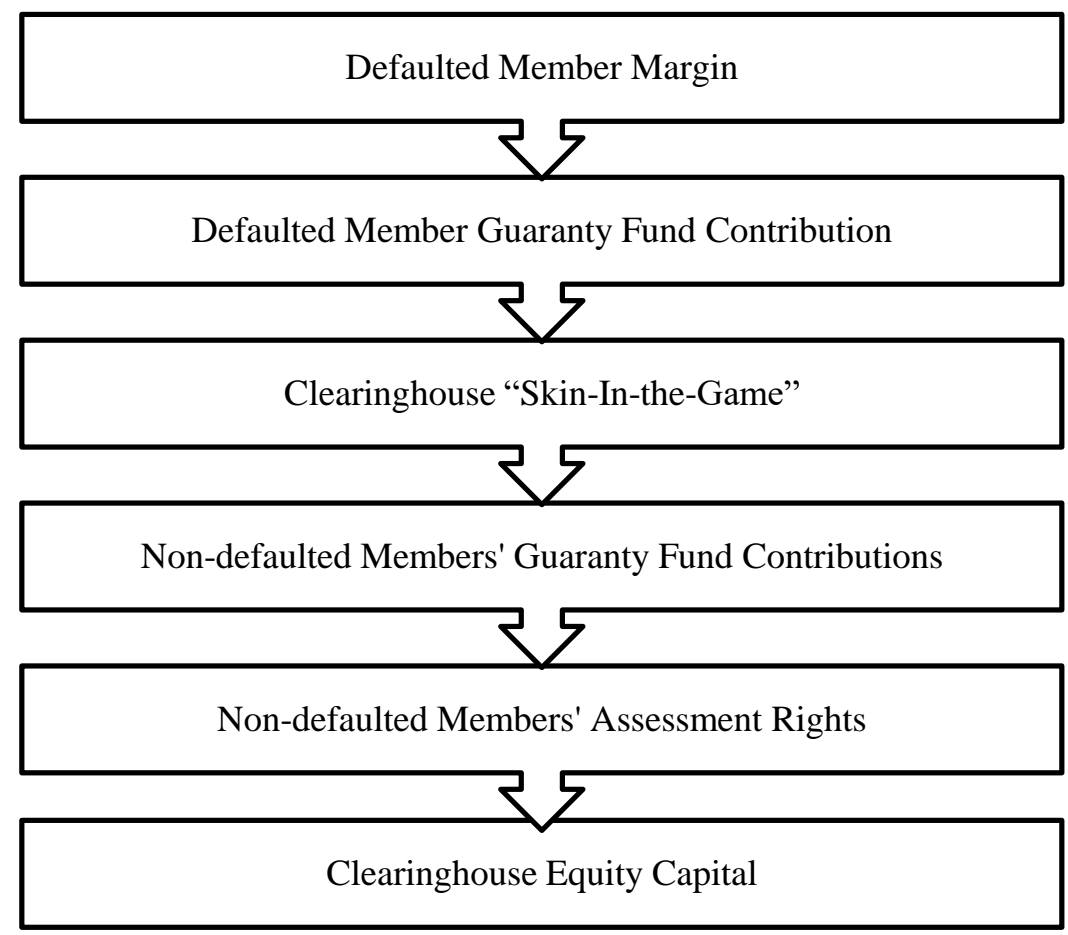

After membership requirements, the second line of defense are the margin requirements. Margin is the first financial resource that can be tapped by a clearinghouse to cover the losses caused by the default of one of its members. ${ }^{97}$ Margin defends against counterparty default risk and operates as a microprudential transactional risk management tool. ${ }^{98}$ Clearinghouses collect margin as collateral to guarantee the performance of cleared and open positions. ${ }^{99}$ These guarantees, which are designed to hedge against the exposure of any cleared transaction, can take the form of initial margin or

97 See Comm. on Payments \& SeTtlement Sys., supra note 80, at 19.

98 See id.

99 See HaSENPUSCH, supra note 60, at 29-31. 
variation margin. ${ }^{100}$ Initial margin, often called "initial performance bond," 101 is collected at the time the transaction is cleared. ${ }^{102}$ In a broad sense, initial margin reflects market volatility, the risk of the underlying transaction, and the creditworthiness of the clearing party. ${ }^{103}$ More specifically, initial margin contributions are intended to cover the future exposures that might arise in the interval between the execution of the contract and either its performance or the close-out and liquidation of the cleared position upon the default of the clearing member. ${ }^{104}$ Variation margin, or "maintenance performance bond," on the other hand, is a "dynamic" guarantee; it reflects market fluctuations in the value of cleared positions, is generally recalculated and marked-to-market daily or intra-daily, and allows clearinghouses to address market risk more effectively. ${ }^{105}$

In addition to the transactional defenses described above, a clearinghouse has in place a unique risk mitigation resource: the default guaranty fund, the third line of defense, which operates as a loss-sharing mechanism that mutualizes losses among clearing members and makes the risk mitigation model of clearinghouses unique. When a defaulted clearing member's margin contributions are not sufficient to absorb the losses of its default, the guaranty fund intervenes. ${ }^{106}$ It acts as a mutualization device and provides a countercyclical, pre-funded cushion of resources to contain (within the clearinghouse perimeter) and mutualize among all clearing

100 See, e.g., CME Group, CME Clearing Risk Management And FiNANCIAL SAFEGUARDS 11 (2018) [hereinafter CME RISK MANAGEMENT], https://www.cmegroup.com/clearing/files/financialsafeguards_v2.pdf [https://perma.cc/2T23-B2EY].

101 Id. at 5.

102 See id. at 11. Margin requirements are generally collected by clearinghouses and held in a segregated account for each individual clearing member.

103 See HASENPUSCH, supra 60, at 29.

104 See CME RISK MANAGEMENT, supra note 100, at 14.

105 See, e.g., id. at $10-11$.

106 See id. at 19. 
members the losses from the default of one or more of them. ${ }^{107}$ Each member must contribute to the guaranty fund in proportion to the volume and riskiness of the portfolio of transactions it submits to be centrally cleared. ${ }^{108}$ The guaranty fund operates in a staggered approach. If, after all the margin pledged by the defaulted member is used, the clearinghouse still needs additional resources to cover the losses of the default and rematch its book, then the capital contributions to the default fund by the defaulted member are used. ${ }^{109}$ Only if all of the guarantees provided by the defaulted member are insufficient to cover its losses are the costs of the default eventually passed down to the non-defaulted members and absorbed by their contributions to the guaranty fund. ${ }^{110}$ The guaranty fund proportionally shares the excess losses among all non-defaulted members. ${ }^{111}$

On top of collateralizing open positions and contributing to the guaranty fund, members are also contractually bound to provide for clearinghouses' financial resilience with additional injections of resources. That is, when the pre-funded financial resources are completely used, the guaranty fund is depleted, and there are still losses to be covered and positions to be rematched, clearinghouses can call or assess members for

107 See e.g., id. at 12. In industry jargon, the ensemble of all financial resources used by a clearinghouse to deal with the default of a clearing member is referred to as the "default waterfall" mechanism, with transaction-specific resources (margin), being used before tapping into the default guaranty fund (mutualization defense). See Saguato, The Ownership of Clearinghouses, supra note 8, at 620-21.

108 See CME RISK MANAGEMENT, supra note 100, at 20.

109 See id. at 11, 20.

110 See CME Risk MANAGEMENT, supra note 100, at 19. Each clearinghouse's default waterfall has a different structure. Generally, after the defaulted members' contributions to the guaranty fund are completely depleted and before the clearinghouse can pass down and mutualize the losses among the non-defaulted members, the clearinghouse contributes to the absorption of the losses with a set amount of resources-their "skin-in-thegame." See id. at 19-20.

111 See id. at 20. 
additional default fund contributions. ${ }^{112}$ Members are contractually required to replenish the guaranty fund when losses are so egregious that they cannot be contained using the pre-funded resources. ${ }^{113}$ In contrast to members' contributions to the guaranty fund-which are countercyclical, prefunded, and adjusted to the risk profile of each member's cleared portfolio-assessment rights are not prefunded, and are triggered only when losses cannot be contained within the already pledged resources. ${ }^{114}$ Due to the way they operate, assessment rights are pro-cyclical-they impose additional liabilities on financial institutions in a market environment that is likely experiencing severe distress.

Finally, a very important piece of the default waterfall is the so-called "skin-in-the-game" that clearinghouses have in the scheme to support their financial resilience. ${ }^{115}$ In addition to the financial resources provided by clearing members, clearinghouses traditionally contribute to their financial resilience with their own capital. ${ }^{116}$ Before a clearinghouse can access the guaranty fund contributions made by non-defaulted members to cover still-open and unmatched positions, it taps into its own capital contributions. ${ }^{117}$ The clearinghouse's skinin-the-game plays a role in absorbing a fraction of default losses. ${ }^{118}$ As the next Section will discuss in more detail, the presence and function of clearinghouse skin-in-the-game in the default waterfall is theoretically intended to align the economic incentives of the clearinghouse to those of its members and to make the firm internalize part of the losses of its

112 See id. at 20-21. In theory, clearinghouse members can be exposed to unlimited liability to keep the clearinghouse business afloat and cover all its losses.

113 See id.

114 See id.

115 See Saguato, The Ownership of Clearinghouses, supra note 8, at $621-22$.

116 See CME Risk MANAGEMENT, supra note 100, at 20.

117 See id.

118 See id. 
business, rather than externalizing them entirely to its members. ${ }^{119}$

The last line of defense is theoretically the clearinghouses' equity capital, which, in the existing loss-allocating mechanisms, is primarily tasked with internalizing any operational or non-default related losses incurred by a clearinghouse in the operation of its business. ${ }^{120}$

Loss mutualization occurs only after all of the defaulted member's resources are used up and the clearinghouse takes the first hit with its skin-in-the-game contribution. ${ }^{121}$ Because of the specific features of the default waterfall and its prefunded and countercyclical nature - that is, the resources of the waterfall are readily available for the clearinghouse when a crisis situation occurs ${ }^{122}$ - the clearinghouse performs a

119 The ratio between members' guaranty fund contributions and clearinghouses' own skin in the game is quite unbalanced, with the clearinghouse's skin-in-the-game representing only a small fraction of the members' skin-in-the-game. See infra Tables 2-5. This situation may create an imbalance between the potential economic exposure of a clearinghouse and that of its members, and polarize the positions of the firm and those of its main stakeholders, rather than aligning them. See infra Part III. See also Saguato, The Ownership of Clearinghouses, supra note 8, at 22.

120 See Rebecca Lewis \& John McPartland, Non-default Loss Allocation at CCPs 5-6 (Fed. Reserve Bank of Chi., Working Paper No. 2017-02, 2017), https://www.chicagofed.org/ /media/publications/policy-discussion-papers/2017/pdp-2017-02-pdf [https://perma.cc/3LLW-SJNE]. See also MKT. Risk Advisory Comm., Commodity Futures Trading Comm’n, Minutes of the Tenth Meeting of the U.S. Commodity Futures Trading CommisSION'S MARKET Risk AdVISORY COMMITTEE (MRAC) 6-7 (2018).

121 Each clearinghouse operates with a different default waterfall. The biggest difference between clearinghouses' default waterfalls is how losses are allocated between non-defaulting members and the clearinghouse. Some firms first call for the complete use of the clearinghouse's skin-in-the-game before losses can be passed down to non-defaulted members; others call for a proportional sharing of losses between the clearinghouse's skin-in-thegame and the guaranty fund.

122 Clearinghouses collect margin and guaranty fund contributions in prosperous times, so that they are readily available during times of distress, characterized by scarce and more expensive capital. From a theoretical perspective, countercyclical financial resources aim at anticipating macrofinancial shocks. That is, firms collect—or perhaps are required to collect-countercyclical resources during periods of "excess aggregate credit growth," when risk is potentially building up in the financial system, so that the firm 
macroprudential function in mitigating systemic risk. In other words, the pre-funded and countercyclical nature of the fund increases the capacity of the clearinghouse to absorb systemic shocks, reduces the likelihood of contagion, and strengthens contractual links among derivatives counterparties even during times of systemic financial distress.

Finally, as the next Section discusses more in detail, a clearinghouse's internal corporate governance structure plays a role in the overall risk management function of the firm. The board of directors, the risk committee, and the oversight committee in particular are the key players in setting, monitoring, and fine-tuning the risk profile of the firm and in creating a safe and sound business model. ${ }^{123}$

\section{B. The Organization of Clearinghouses: Markets, Ownership, and Governance Structure}

Clearinghouses have been stitched into the weaves of financial markets for the last two centuries. ${ }^{124}$ Securities, derivatives, and payment markets substantially rely on clearinghouses as primary enhancers of their efficiency and stability. ${ }^{125}$

has sufficient financial resources to absorb losses during a recession or if financial markets experience distress and defaults of banks. See, e.g., BASEL Comm. on Banking Supervision, Frequently Asked Questions on the BASEL III COUNTERCYCLICAL CAPITAL BUFFER 1 (2015). See also Countercyclical Capital Buffer (CCyB), BANK FOR INT'L SETTLEMENTS (May 13, 2020), https://www.bis.org/bcbs/ccyb/ [https://perma.cc/94QJ-ZRYZ]; Randal K. Quarles, Vice Chair for Supervision, Fed. Reserve Sys., Speech at the Meeting of the Manhattan Institute's Shadow Open Market Committee: Frameworks for the Countercyclical Capital Buffer 3 (Mar. 29, 2019), https://www.federalreserve.gov/newsevents/speech/quarles20190329a.htm [https://perma.cc/H3T5-CB5P].

123 See infra notes 166-68 and accompanying text. See also Part V (discussing policy solutions on how to strengthen clearinghouses governance and resilience).

124 See Yadav, supra note 9, at 389, 406.

125 See Norman, supra note 15, at 3-6; Randall S. Kroszner, Can the Financial Markets Privately Regulate Risk? The Development of Derivatives Clearinghouses and Recent Over-the-Counter Innovations, 31 J. MoNEY, CREDiT \& BANKING 596, 598-604 (1999). 
Born from the private initiative of market participants to reduce transaction costs in the post-trading ecosystem, clearinghouses historically developed as mutual firms. ${ }^{126}$ They were traditionally set up by a small number of financial institutions dealing in mutual trades, ${ }^{127}$ and they were originally

126 See, e.g., Reena Aggarwal, Demutualization and Corporate Governance of Stock Exchanges, 15 J. APPLIED CORP. FIN. 105 (2002); Andreas M. Fleckner, Stock Exchanges at the Crossroads, 74 FoRDHAM L. REV. 2541 (2006); Oliver Hart \& John Moore, The Governance of Exchanges: Members' Cooperatives Versus Outside Ownership, 12 OxFORD REV. ECON. POL'Y 53 (1996); Roberta S. Karmel, Turning Seats into Shares: Causes and Implications of Demutualization of Stock and Futures Exchanges, 53 HASTINGs L.J. 367 (2002). The emergence of clearinghouses as firms in both the securities and futures markets represents a fascinating practical application of the Coasean view of the firm. In one of his seminal works, Ronald H. Coase investigated why firms emerge in specialized exchange economies with a functioning price mechanism (i.e., markets). In that piece Coase argued that economic activities are organized within the firm and thus firms are established and supersede markets when transaction costs are higher than organization costs. See R.H. Coase, The Nature of the Firm, 4 EconOMICA 386 (1937). Coase in The Nature of the Firm never used the term "transaction costs"-however he did talk about the costs associated with operating markets and of using the price mechanism. See id. at 392, 395. Nevertheless, this piece has been considered the first contribution to the "new institutional economic" approach to economic analysis. In the post-trading environment, the costs for market participants to deal bilaterally in handling executed transactions was higher than the costs of creating a specialized firm tasked with the specific risk management and trade clearance functions.

127 The historical evolution of clearinghouses parallels the development of the early stock and futures exchanges. The establishment of a clearinghouse-either upon the initiative of the exchange itself, or by some of its members-generally follows the establishment of trading platforms. See Randall S. Kroszner, Central Counterparty Clearing: History, Innovation, and Regulation, 30 ECON. PERSP. 37, 37-39 (2006). That is, once after-market participants decided to move from pure bilateral transactions to a centralized and multilateral trading environment, they established the first exchanges for financial instruments. See id at 38. By moving from bilateral markets to centralized venues, market participants were able to (1) reduce transaction costs and information asymmetries and (2) increase market liquidity and price accuracy. However, the increase in volume of executed transactions also increased the need for resilient back-office services. See id at 39. While trades were executed in a centralized and multilateral environment, post-trading was still handled bilaterally. Consequently, trading members started to face the growing costs of processing executed trades. See 
organized as member-owned enterprises, either owned directly by the clearing members or structured as wholly-owned subsidiaries or business units of an exchange, ${ }^{128}$ which was in turn mutually owned by the very same trading and clearing members. ${ }^{129}$ Historically, being a clearing member was linked to being an owner (either shareholder or partner) of the clearing firm, and the two qualities could not be decoupled. ${ }^{130}$ Clearinghouses-as well as securities and derivatives exchanges-were operated as cooperatives responsible for managing the financial risk of their members, reducing the overall exposure and risk of those members, and providing a clear mechanism for the orderly management of those members' eventual default. ${ }^{131}$ Traditionally, clearinghouse members ex ante agreed to internalize and share any costs associated with the eventual default of any other member, and all participated

id at 39. Support of the performance and settlement of executed transactions was addressed with the creation of specialized post-trading and risk management firms: clearinghouses. Academic scholarship has substantially overlooked the organization of post-trading firms, because of both the more obscure and structural function of back-office firms and the fact that posttrading firms rarely interact with investors.

128 Law and economics scholarship has looked into the economic incentives that justify the different organizational structures that firms may adopt. In particular, Henry Hansmann's seminal work on the ownership of enterprise focuses on why some firms are owned by investors or capital providers, while other firms are owned by other stakeholders like employees, customers, members, suppliers, or a combination thereof. See HENRY HANSMANN, THE OWNERSHIP OF ENTERPRISE (1996). His work offers some very insightful perspectives as to why the first stock and derivatives exchanges were organized as mutual firms. Additionally, Hansmann's scholarship furthers the understanding as to why in the early 2000s many stock and futures exchanges demutualized their ownership structure. However, Hansmann's theories do not explain the current organization of modern derivatives clearinghouses, leaving the question open on why financial institutions acting as clearing members agreed to demutualize and give up their ownership of clearinghouses while at the same time agreeing to maintain the loss mutualization mechanism.

129 For a more comprehensive account of the historical evolution of the clearing industry, see Saguato, The Ownership of Clearinghouses, supra note 8 , at $623-30$.

130 See, e.g., LEE, supra note 15, at 145-46.

131 See Kroszner, supra note 127, at 37-40. 
in the governance of the firm. ${ }^{132}$ Simply put, the stakeholders with full "skin-in-the-game" were those that managed the risk of the firm and were completely accountable for its operations.

The current post-trading environment, however, is different from what it once was. In the 1970 s, securities and derivatives markets adopted different market structures, with securities markets embracing a horizontal model of specialized, stand-alone post-trading mutual firms, and derivatives markets maintaining the vertically integrated silo structure. ${ }^{133} \mathrm{In}$ addition, starting in the 2000 s, derivatives market infrastructures and stock exchanges further diverged from the traditional mutual structure of trading and post-trading firms, and opened their capital to external equity investors, ${ }^{134}$ demutualizing their ownership, ${ }^{135}$ and starting a season of consolidation of market infrastructures. ${ }^{136}$ However, an interesting and underappreciated aspect of the demutualization of derivatives exchanges was the fact that, while the demutualization happened at the ownership level, the clearinghouses of the group maintained the mutualized loss-sharing mechanism of the default guaranty fund. ${ }^{137}$ Therefore, clearinghouses demutualized their ownership to external shareholders, but still mutualized their risks and losses on their members. ${ }^{138}$

Member-owned clearinghouses still exist and are pillars in the securities markets. For one example, the Depository Trust

132 See id.

133 See Saguato, The Ownership of Clearinghouses, supra note 8, at 623-25.

134 See id. at 626.

135 See id. at 626-30.

136 See Ferrarini \& Saguato, supra note 16 (providing the first account of financial market infrastructure ("FMI") organizations as the dominant players in the securities and derivatives markets).

137 See generally Saguato, The Ownership of Clearinghouses, supra note 8 , at 640-52. The separation of ownership from clearing participation and loss mutualization was first described by Robert Cox and Robert Steigerwald as "incomplete demutualization." See Robert T. Cox \& Robert S. Steigerwald, "Incomplete Demutualization" and Financial Market Infrastructure: Central Counterparty Ownership and Governance After the Crisis of 2008-9, 4 J. Fin. MKT. INFRASTRUCTURES 25 (2016).

138 See Cox \& Steigerwald, supra note 137, at 31-32. 
and Clearing Corporation ("the DTCC") is the member-owner market utility that provides post-trading services to securities market participants through its subsidiaries. ${ }^{139}$ However, the two major players in the derivatives clearing markets are investor-owned enterprises: the Chicago Mercantile Exchange Group ("the CME Group") and its clearing division, ${ }^{140}$ along with ICE Clear Credit, which is part of the Intercontinental Exchange Group ("ICE"). ${ }^{141}$ Derivatives clearinghouses are subsidiaries or business units of large, vertically integrated, for-profit public corporations, which are listed on stock exchanges. ${ }^{142}$ In between member-owned and investor-owned clearinghouses stands the Option Clearing Corporation ("the OCC"), an exchange-owned clearinghouse for options. ${ }^{143}$

Table 1 summarizes the current landscape of systemically important clearinghouses operating in U.S. financial markets, identifying the ownership models adopted by clearing firms, the markets in which they operate, and their market structure.

139 See Katie Kolchin, Spotlight: DTCC's Important Role in US CAPITAL MARKETS 2-3 (2019), https://www.sifma.org/resources/research/sifmainsights-spotlight-dtcc/ [https://perma.cc/2P2Y-55SN].

140 See CME Group Overview, CME GROUP, https://www.cmegroup.com/company/history/ [https://perma.cc/D5CA-VU3F] (last visited May 11, 2020).

141 See ICE Clear Credit, InTERCONTINENTAL ExCHANGE, https://www.theice.com/clear-credit [https://perma.cc/5C63-JZ83] (last visited May 15, 2020).

142 For instance, CME Group is listed on Nasdaq and the Intercontinental Exchange is listed on the New York Stock Exchange. See CME Group Inc. Class A Common Stock (CME), NASDAQ, https://www.nasdaq.com/market-activity/stocks/cme [https://perma.cc/C9X9-LBN4] (last visited July 1, 2020); Intercontinental Exchange Inc. ICE, NYSE, https://www.nyse.com/quotes [https://perma.cc/B3MR-SW7L] (last visited July 1, 2020).

143 See Option Clearing Corp., OCC FACT Sheet 1 (2020), https://ncuoccblobdev.blob.core.windows.net/media/theocc/media/about/occfactsheet.pdf [https://perma.cc/RCW7-GJLG]. 
Table 1: U.S. systemically important clearinghouses ${ }^{144}$

\begin{tabular}{|l|l|l|l|}
\hline $\begin{array}{l}\text { Systemically } \\
\text { Important } \\
\text { FMIs }\end{array}$ & $\begin{array}{l}\text { Business } \\
\text { Description }\end{array}$ & $\begin{array}{l}\text { Ownership } \\
\text { Structure } \\
\text { (Parent and } \\
\text { Group) }\end{array}$ & $\begin{array}{l}\text { Market } \\
\text { Structure }\end{array}$ \\
\hline $\begin{array}{l}\text { Chicago } \\
\text { Mercantile } \\
\text { Inchange, }\end{array}$ & $\begin{array}{l}\text { Central clearing } \\
\text { counterparty of ex- } \\
\text { change-traded and } \\
\text { OTC futures, options, } \\
\text { and swaps (exchange- } \\
\text { trade and OTC) }\end{array}$ & $\begin{array}{l}\text { Investor- } \\
\text { owned sub- } \\
\text { sidiary of the } \\
\text { CME Group } \\
\text { Inc. (listed } \\
\text { company) }\end{array}$ & $\begin{array}{l}\text { Vertically in- } \\
\text { tegrated } \\
\text { (open) silo145 }\end{array}$ \\
\hline $\begin{array}{l}\text { ICE Clear } \\
\text { Credit LLC }\end{array}$ & $\begin{array}{l}\text { Central clearing } \\
\text { counterparty of credit } \\
\text { default swaps }\end{array}$ & $\begin{array}{l}\text { Investor- } \\
\text { owned sub- } \\
\text { sidiary of } \\
\text { ICE (listed } \\
\text { company) }\end{array}$ & $\begin{array}{l}\text { Vertically in- } \\
\text { tegrated } \\
\text { (open) silo }\end{array}$ \\
\hline $\begin{array}{l}\text { The Options } \\
\text { Clearing Cor- } \\
\text { poration }\end{array}$ & $\begin{array}{l}\text { Central clearing } \\
\text { counterparty of US } \\
\text { listed options }\end{array}$ & $\begin{array}{l}\text { Exchange- } \\
\text { owned }\end{array}$ & Mixed $^{147}$ \\
\hline $\begin{array}{l}\text { National } \\
\text { Securities } \\
\text { Clearing } \\
\text { Corporation }\end{array}$ & $\begin{array}{l}\text { Central clearing } \\
\text { counterparty of equity } \\
\text { securities and corpo- } \\
\text { rate/municipal debt }\end{array}$ & $\begin{array}{l}\text { Member- } \\
\text { owned sub- } \\
\text { sidiary of } \\
\text { DTCC }\end{array}$ & $\begin{array}{l}\text { Horizontal } \\
\text { structure }\end{array}$ \\
\hline $\begin{array}{l}\text { Fixed Income } \\
\text { Clearing } \\
\text { Corporation }\end{array}$ & $\begin{array}{l}\text { Central clearing } \\
\text { counterparty of gov- } \\
\text { ernment securities, } \\
\text { mortgage-backed se- } \\
\text { curities }\end{array}$ & $\begin{array}{l}\text { Member- } \\
\text { owned sub- } \\
\text { sidiary of } \\
\text { DTCC }\end{array}$ & $\begin{array}{l}\text { Horizontal } \\
\text { structure }\end{array}$ \\
\hline
\end{tabular}

This Article primarily focuses on derivatives clearinghouses, given their increasing importance in the U.S. (and

144 See Fin. Stability Oversight Council, 2012 AnNual RePort 110 12, 119, 145-87 (2012) [hereinafter FSOC REPORT].

$145 \mathrm{CME}$ offers its clearing services to contracts executed on platforms other than the CME Exchange. See CME RuLEBooK, supra note 25, § 8C01.

146 ICE Clear Credit also offers clearing services to contracts executed on platforms that do not belong to the Intercontinental Exchange group. See ICE Clear CREdit, Clearing Rules, supra note 25, at 45-46.

147 The OCC offers its clearing services to twenty exchanges and trading platforms that process options, financial futures, security futures and securities lending transactions. See OPTION ClEARING CORP., OCC ANNUAL REPORT 2019 47-48 (2019). 
global) financial markets due to the implementation of postcrisis reforms that channeled trillions of dollars' worth of transactions through clearinghouses by mandating their use to mitigate and manage systemic risk in the derivatives markets. ${ }^{148}$ Furthermore, because of clearinghouses' systemic importance, policymakers have become particularly interested in ensuring their sound management and systemic resilience. ${ }^{149}$ However, a challenge that policymakers have so far overlooked - and therefore have not addressed-is the unique agency costs, and potentially conflicting interests, that investor-owned clearinghouses pose.

As wholly-owned subsidiaries of a listed corporation, or as one of its internal divisions, a clearinghouse's directors are either the directors sitting on the board of the controlling firm or are appointed by the board of the controlling firm. ${ }^{150}$ The managers of the clearinghouse-as agents of the corporation and its shareholders-have a duty to maximize shareholders' value. ${ }^{151}$ Shareholders, as residual claimants of the corporation, are entitled to receive its revenues and should bear the tail risk of the business - at least up to the amount of their

148 See Peirce, supra note 9, at 594.

149 See e.g. J. Christopher Giancarlo, Chairman, Commodity Futures Trading Comm'n, The Tao of Derivatives Clearing: Clearinghouse Resiliency, Recovery and Resolution (May 10, 2019), https://www.cftc.gov/PressRoom/SpeechesTestimony/opagiancarlo72 [https://perma.cc/3KMN-9P3J].

150 See infra Section IV.B.

151 It is outside the scope of this Article to discuss the complex issue of the corporate purpose. For completeness, the corporate purpose theory of "shareholder primacy" claims that the duty of management is to maximize shareholders' value. See Dodge v. Ford Motor Co., 170 N.W. 668, 668 (Mich. 1919) (one of the most famous corporate law judicial decisions, stating that "[a] business corporation is organized primarily for the profit of the stockholders"). See also Henry Hansmann \& Reinier Kraakman, The End of History for Corporate Law, 89 GEO. L.J. 439 (2001); William W. Bratton \& Michael L. Wachter, Shareholder Primacy's Corporatist Origins: Adolf Berle and the Modern Corporation, 34 J. CoRP. L. 99 (2008). Even critics of the strict application of this theory agree that it accurately describes the primary, general purpose of most corporate actions. See Lynn A. Stout, Bad and Not-So-Bad Arguments for Shareholder Primacy, 75 S. CAL. L. REV. 1189 (2002). 
capital investment. ${ }^{152}$ However, because of their unique economic structure, clearinghouses are unconventional corporations. All systemically important derivatives clearinghouses operate with a "double layered capital": the equity capital provided by the firm's shareholders is substantially shielded from losses by the guaranty fund, which is fully contributed to by clearing members. ${ }^{153}$ Derivatives clearinghouses and their shareholders wholly rely on their clearing members not just for their business - and the revenues that they extract from them-but also, critically, to financially support clearing operations. ${ }^{154}$

However, as next Section analyzes in more detail, the unique economic structure of clearinghouses does not reflect a unique organizational or governance structure. Clearinghouses' corporate governance does not differ from that of any other corporation. ${ }^{155}$ A clearinghouse's shareholders-its holding company, and, indirectly, its holding company's shareholders-have full control rights. They appoint the directors who sit on its board, ${ }^{156}$ and the board appoints the officers of the corporation. Members, as such, are not given any formal governance or control rights in the clearinghouse in

152 The notion and regime of shareholders as residual claimants of the corporation has its foundation in the principle of limited liability. See Henry Hansmann \& Kraakman, supra note 37, at 390, 393-94 (defining asset partitioning); Henry Hansmann et al., Law and the Rise of the Firm, 119 HARV. L. REV. 1333, 1337, 1339-40 (2006) (defining owner shielding); Henry Hansmann \& Richard Squire, External and Internal Asset Partitioning: Corporations and Their Subsidiaries, in THE OXFORD HANDBOOK OF CORPORATE LAW AND GovernANCE 251, 253-66 (Jeffrey N. Gordon \& Wolf-Georg Ringe eds., 2018) (expanding on the effect of external and internal corporate partitioning on corporate groups).

153 See Saguato, The Ownership of Clearinghouses, supra note 8, at 633-34.

154 See id. at 633.

155 Or, like in the case of ICE Clear Credit, any limited liability company.

156 The directors of clearinghouses are either directors of the holding company itself-like in the CME Inc. case-or they are appointed by the board of directors of the holding company-like in the ICE Clear Credit case. See infra Section IV.B. 
return for their contributions to the guaranty fund and for being required to internalize the risk mutualization costs. ${ }^{157}$

Because of their responsibility as systemic risk managers, a critical role in the governance of a clearinghouse is (or should be) played by the risk committee of its board of directors. ${ }^{158}$ A clearinghouse's risk committee is responsible for overseeing the risks that the firm faces and advising the board on any risk-related issues. ${ }^{159}$ The risk committee generally reviews and assesses the risk management practices of the firm (i.e., membership requirements, margin calculations, determinations of guaranty fund contributions, etc.), advises the board as to the effectiveness of its compliance policies and practices and assists the board in its members' admissions processes and in the financial oversight of the business. ${ }^{160}$ While traditionally comprised of clearinghouses' officers and external experts, the majority of risk committees now have a strong representation of clearing members. ${ }^{161}$ In changing the composition of risk committees in this way, clearinghouses have tried to rebalance the unstable structure of their incomplete demutualization by offering the final risk bearers of their business a say-albeit only an advisory one-in risk-related matters.

The effectiveness and actual influence of risk committees is not easy to assess. On the one hand, the legal framework does not provide any actual authority or binding power to risk committees or their decisions, and it does not envision any special procedure that a board of directors needs to follow if it intends to disregard a risk committee's recommendations-

157 See id.

158 See Chi. Mercantile Exch. Inc., Clearing House Risk Committee Charter 1 (2019); ICE Clear Credit, ICE Clear Credit Regulation and GOVERNANCE 3-4 (2019), https://www.theice.com/publicdocs/clear_credit/ICE_Clear_Credit_Regulation_and_Governance.pdf [https://perma.cc/N4MZ-U73N].

159 See CHI. MERCANTILE EXCH. INC., supra note 158, at 2-3; ICE CLEAR CREDIT, supra note 158 , at 3-4.

160 See CHI. Mercantile ExCH. InC., supra note 158, at 2-3; ICE CLEAR CREDIT, supra note 158 , at 3-4.

161 See CHI. MERCANTILE EXCH. INC., supra note 158, at 1-2; ICE CLEAR CREDIT, supra note 158 , at 3. 
the board of directors retains the ultimate decision-making authority over the clearing business. ${ }^{162}$ On the other hand, clearing industry participants, while acknowledging the lack of specific rules on governance arrangements and risk management, recognize the existence of a strong risk management culture at clearinghouses and admit the practical influence of clearing members in the risk management of firms. ${ }^{163}$ They also acknowledge the real deference of boards to their risk committee on risk-related issues, under the threat of exposure to liability for breach of fiduciary duties on the part of the directors. ${ }^{164}$

Tables 2-5 look at the skin-in-the-game contributions of the major U.S. derivatives clearinghouses and compares them to other relevant capital variables. Tables $2-5$ reflect the significant imbalance of the economic exposure of clearing members vis-à-vis clearinghouses and their holding groups. This imbalance, as is discussed in more detail in the next Section, results in the misaligned incentives of members and shareholders, which creates agency costs between the firms' primary stakeholders that threaten clearinghouses' systemic resilience.

The first column of each table notes the amount of each clearinghouse's skin-in-the-game in its own default waterfall. Table 2 shows the ratio of the firm's skin-in-the-game contribution to the total amount of the guaranty fund provided by the members. Table 3 describes the proportion of firms' capital allocated to absorb the default of clearing members, with the overall equity capital of the holding company controlling the clearinghouse. Table 4 looks at the ratio of clearinghouses' skin-in-the-game and their equity capital-the ultimate financial resource available to absorb non-default operational losses. And finally, Table 5 compares clearinghouses' skin-in-

162 See infra Section IV.B (describing the governance practices and policies of the major U.S. clearinghouses).

163 This statement is supported by "deep background" conversations the author has had with multiple clearing industry sources from January 2016 to July 2020.

164 This statement is supported by "deep background" conversations the author has had with multiple clearing industry sources from January 2016 to July 2020. 
the-game to their total assets. Together, these numbers show how modest the economic exposure of clearinghouses are to their own business and how much holding companies externalize onto members the risk of clearinghouses. 
Table 2: Clearinghouses' Skin-in-the-Game and Guaranty Fund ${ }^{165}$

\begin{tabular}{|l|c|c|c|}
\hline Firm & $\begin{array}{l}\text { Skin in the } \\
\text { (SiG) (\$) }\end{array}$ & $\begin{array}{l}\text { Guaranty } \\
\text { Fund (\$) }\end{array}$ & $\begin{array}{l}\text { SiG/Guaranty } \\
\text { Fund }\end{array}$ \\
\hline CME Inc. Base & $100 \mathrm{M}$ & $4.92 \mathrm{~B}$ & $2 \%$ \\
\hline CME Inc. (IRS) & $150 \mathrm{M}$ & $3.36 \mathrm{~B}$ & $4.2 \%$ \\
\hline $\begin{array}{l}\text { ICE Clear } \\
\text { Credit }\end{array}$ & $50 \mathrm{M}$ & $2.90 \mathrm{~B}$ & $1.67 \%$ \\
\hline
\end{tabular}

Table 3: Clearinghouses' skin-in-the-game and FMI equity

\begin{tabular}{|l|c|c|c|}
\hline Firm & $\begin{array}{l}\text { Skin in the } \\
\text { (SiG) (\$) }\end{array}$ & $\begin{array}{l}\text { Equity } \\
\text { FMI } 16 \mathbf{7}\end{array}$ & $\begin{array}{l}\text { SiG/ Equity } \\
\text { FMI }\end{array}$ \\
\hline $\begin{array}{l}\text { CME Inc. } \\
\text { (Base) }\end{array}$ & $100 \mathrm{M}$ & $26.13 \mathrm{~B}$ & $0.38 \%$ \\
\hline $\begin{array}{l}\text { CME Inc. } \\
\text { (IRS) }\end{array}$ & $150 \mathrm{M}$ & $26.13 \mathrm{~B}$ & $0.57 \%$ \\
\hline $\begin{array}{l}\text { ICE Clear } \\
\text { Credit }\end{array}$ & $50 \mathrm{M}$ & $17.26 \mathrm{~B}$ & $0.29 \%$ \\
\hline
\end{tabular}

165 CME IRS includes IRS products. See CME RIsk MANAGEMEnT, supra note 100. Ice Clear Credit clears single-name and index credit default swaps. See ICE Clear Credit, InTERCONTINENTAL ExCHANGE, https://www.theice.com/clear-credit [https://perma.cc/PQ32-Y7BT] (last visited July 1, 2020).

166 See CME Clearing's Financial Safeguards System, CME Group, https:/www.cmegroup.com/clearing/cme-clearing-overview/safeguards.html [https://perma.cc/8E5S-K8TN] (last visited July 1, 2020); ICE Clear Credit: Financial Resources, InTERCONTINENTAL ExCHANGE, https://www.theice.com/clear-credit/regulation [https://perma.cc/748E7XJE] (last visited July 1, 2020).

167 See CME Group Inc., Annual Report (Form 10-K) 27 (Feb. 28, 2020); Intercontinental Exchange, Annual Report (Form 10-K) 85 (Feb. 6, 2020). 
Table 4: Clearinghouses' skin-in-the-game and clearinghouse equity

\begin{tabular}{|l|c|c|c|}
\hline Firm & $\begin{array}{l}\text { Skin in } \\
\text { the } \\
\text { (SiG) (\$) }\end{array}$ & $\begin{array}{l}\text { Clearinghouse } \\
\text { Equity (\$) }\end{array}$ & $\begin{array}{l}\text { SiG8 } \\
\text { Equity }\end{array}$ \\
\hline $\begin{array}{l}\text { CME Inc. } \\
\text { (Base) }\end{array}$ & $100 \mathrm{M}$ & $1.01 \mathrm{~B}$ & $9.1 \%$ \\
\hline $\begin{array}{l}\text { CME Inc. } \\
\text { (IRS) }\end{array}$ & $150 \mathrm{M}$ & $1.01 \mathrm{~B}$ & $13.65 \%$ \\
\hline $\begin{array}{l}\text { ICE Clear } \\
\text { Credit }\end{array}$ & $50 \mathrm{M}$ & $208 \mathrm{M}$ & $24 \%$ \\
\hline
\end{tabular}

Table 5: Clearinghouses' skin-in-the-game and clearinghouse assets

\begin{tabular}{|c|c|c|c|}
\hline Firm & $\begin{array}{l}\text { Skin in the } \\
(\mathrm{SiG})(\$)\end{array}$ & $\begin{array}{l}\text { Total As- } \\
\text { sets }^{169}\end{array}$ & $\begin{array}{l}\text { SiG/Total } \\
\text { Asset }\end{array}$ \\
\hline $\begin{array}{l}\text { CME Inc. } \\
\text { (Base) }\end{array}$ & $100 \mathrm{M}$ & $38.89 \mathrm{~B}$ & $0.26 \%$ \\
\hline $\begin{array}{l}\text { CME Inc. } \\
\text { (IRS) }\end{array}$ & $150 \mathrm{M}$ & 38.89B & $0.36 \%$ \\
\hline $\begin{array}{l}\text { ICE Clear } \\
\text { Credit }\end{array}$ & $50 \mathrm{M}$ & $24.66 \mathrm{~B}$ & $0.20 \%$ \\
\hline
\end{tabular}

By building on these numbers and focusing on the economic structure and allocation of final risk and control rights in clearinghouses, the next Section offers a theoretical framework through which to understand the existing, unaddressed imbalance between members and shareholders in the capital structure and governance of investor-owned clearinghouses.

168 The equity referred to in this column is the equity capital of the subsidiary that provides clearing services, not the equity capital of the consolidated group holding company.

169 See Chi. Mercantile Exch. Inc., Financial Statements 3 (2019), http://investor.cmegroup.com/static-files/586f1c03-0dc8-4af4-b7ce849bda7f4205 [https://perma.cc/J7QX-N6XL]; ICE ClEAR CREDIT LLC, FINANCIAL STATEMENTS 2 (2020), https://www.theice.com/publicdocs/regulatory_filings/ICE_Clear_Credit_Financial_Statements_2018_2019.PDF [https://perma.cc/CL5P-UQL5]. 


\section{THE AGENCY COSTS OF THE MEMBER- SHAREHOLDER DIVIDE}

As previously mentioned, clearinghouses are for-profit corporations owned by a publicly listed company, but they operate with a capital structure that mutualizes risks among users and allocates the ultimate costs of losses onto their members - that is, the providers of the guaranty fund-and not onto shareholders. Control rights over clearing firms, as well as election rights for their boards of directors, are retained by firms' shareholders. ${ }^{170}$ The economic rights of participation in the profits of the clearing business are also held by shareholders; ${ }^{171}$ however, the final risks of the business are all allocated to clearing members. Thus, the stakeholders with actual skinin-the-game in the business and a direct interest in establishing robust risk management policies and practices, do not have any formal ${ }^{172}$ legal representation on clearinghouses' boards of directors, nor any formal or binding say in firms' risk management.

This situation is peculiar. The decoupling of final riskbearing costs from control rights creates a unique economic and governance structure that reverses the traditional view of the corporation, in which shareholders are considered the residual claimants and the final bearers of any business risk, and are therefore given control rights over the firm. ${ }^{173}$ Here, shareholders shift the costs of running the business onto firms' users. The structure of the default waterfall, with the guaranty fund provided by the members and the right of the clearinghouse to call on additional financial contributions (i.e., assessment rights), perpetuates this externalization of costs onto clearinghouses' main stakeholders.

This creates a new type of delicate and risky agency cost between clearinghouses (and their shareholders, the agents)

170 See infra Section IV.B.

171 See Saguato, The Ownership of Clearinghouses, supra note 8, at 632-33.

172 The use of "formal" here means as required by laws or regulations.

173 See Griffith, supra note 9, at 1219. 
and their members (the principals). ${ }^{174}$ This new agency cost, which stems from the "member-shareholder divide,"175 manifests in misaligned incentives between clearing members and clearinghouses (and their shareholders). ${ }^{176}$ This could potentially create moral hazard and ultimately undermine clearinghouses' systemic resilience. ${ }^{177}$

Clearinghouses face serious governance issues. ${ }^{178}$ Corporate governance has traditionally been the primary mechanism to reduce agency costs. ${ }^{179}$ In public corporations, independent directors play an important role in monitoring managers; in addition, particularly in financial firms, the risk committee is a vital source of support for the board. ${ }^{180}$ As subsidiaries of public corporations, clearinghouses indirectly face the same agency costs that derive from the separation of ownership and control. Directors and officers of the firm (i.e., agents), while pursuing the maximization of the firm's value (i.e., shareholders' value), are bound to contractual

174 See Saguato, The Hidden Costs of Clearinghouses, supra note 8 (manuscript at 25-28).

175 See Saguato, The Ownership of Clearinghouses, supra note 8, at 606-07 (defining this unique feature of the ownership structure of modern clearinghouses).

176 See Wenqian Huang, Central Counterparty Capitalization and Misaligned Incentives 4 (Bank for Int'l Settlements, Working Paper No. 767, 2019), https://www.bis.org/publ/work767.htm [https://perma.cc/2K9UW5PE].

177 See id. at 5. Huang's interesting theoretical piece asserts that forprofit clearinghouses with limited liability have incentives that are misaligned with the financial stability function they perform in the market. See id. at 4 .

178 See Robert Steigerwald, Senior Policy Advisor, Fed. Reserve Bank of Chi., Clearinghouse Risk Management and Governance Today 62-63, 135-38 (Dec. 4, 2018), https://www.cftc.gov/sites/default/files/2019/07/1563562184/mrac_120418_transcript.pdf

[https://perma.cc/R9TL-3JAZ] (discussing the misaligned incentives between clearinghouses and their shareholders and clearing members due to the capital structure of clearinghouses).

179 See e.g., Daniel R. Fischel, The Corporate Governance Movement, 35 VAND. L. REV. 1259, 1262-65 (1982).

180 See Paolo Saguato, Financial Market Infrastructures: The Essential Role of Risk Management, in Governance OF FinANCIAL INSTITUTIONs 228, 240-41 (Danny Busch et al. eds., 2019). 
arrangements and subject to fiduciary duties owed to shareholders and to the corporation in order to keep their incentives aligned with those of their principal, the corporation (and, indirectly, its shareholders). The governance framework is potentially complicated by the double-layered capital structure of clearinghouses and the fact that the allocation of risk-bearing costs should result in the allocation of control rights. ${ }^{181}$ The directors of a clearinghouse do not owe fiduciary duties to clearing members; ${ }^{182}$ while it is recommended that they engage with members and customers on any matters related to risk management, there are no mechanisms to make the clearing members' voice binding for the directors, nor do members have any mechanism to disavow a board's decision on matters related to the risk management of the firm.

The current allocation of control rights and final risk-bearing costs creates a serious imbalance in the governance structure of clearinghouses. The stakeholders who set the risk profile and appetite of the firm and who have a formal say in its risk management are not the ones who would bear the actual, ultimate risk if things were to go south. This situation exacerbates the moral hazard of the clearinghouse: by not bearing the costs of the business and only participating in the profit of the venture, ${ }^{183}$ clearinghouses might be induced to water down their risk management standards in order to attract more clearing volume, thereby generating more fees and profit to eventually distribute to the holding firm. ${ }^{184}$

In other regulated industries where firms impose externalities on their stakeholders or on society as a whole, regulators

181 See Saguato, The Ownership of Clearinghouses, supra note 8, at 632-33, 647-48.

182 See id. at 637 n. 125.

183 Formally, shareholders participate in the default waterfall with their skin-in-the-game contributions before contributions of the non-defaulted members are used. In addition, the amount of skin-in-the-game contributed is minimal compared to the size of the guaranty fund or the market capitalization of the whole infrastructural group. See infra Tables 2-5.

${ }^{184}$ Examples of degradations in risk management are: the lowering of membership requirements, the acceptance of highly volatile and risky products for clearing, broadening the types of assets deemed acceptable as collateral, and the re-use of pledged collateral in leveraged transactions. 
often counterbalance the (negative) effects of the limited liability of the business entities and their shareholders by imposing either capital requirements-as is particularly the case in the financial sector ${ }^{185}$ - or by requiring firms to carry insurance to cover the costs that are passed down to society. Both mechanisms are intended to force firms to internalize the costs they impose on the economy and to mitigate firms' risk appetite, in the former way by increasing firms' skin-in-thegame, and in the latter by having the market price the risk. In the clearinghouse context, however, the existing regulation does not set minimum capital requirements for clearinghouses, nor does it set criteria to calibrate the amount of skinin-the-game clearinghouses must contribute in the default waterfall. An analysis of market data reveals that clearinghouses only contribute a thin capital contribution to the default waterfall compared to the skin-in-the-game contributed by clearing members. ${ }^{186}$ For this reason, the effectiveness of skin-in-the-game contributions as a mechanism to internalize the costs of the potential externalities of the clearing business is very limited. The existing loss allocation scheme creates a very unstable capital structure that exacerbates the exposure of clearinghouses to moral hazard and might intensify clearinghouses' risk-taking incentives.

The moral hazard that results from the separation of risk and control is further exacerbated by the too-big-to-fail role that clearinghouses have in post-crisis financial markets. ${ }^{187}$ Clearinghouses are part of large, for-profit financial conglomerates and have been entrusted with the specific public policy function of maintaining financial stability in the derivatives markets. ${ }^{188}$ This double purpose might cause clearinghouses (and their holding companies) to leverage their current tooimportant-to-fail role by taking on excessive risk in the clearing business or embarking on risky corporate acquisitions or

185 See generally David Andrew Singer, Regulating CAPITAL: SETTING STANDARDS FOR THE INTERNATIONAL FINANCIAL SYSTEM (2007).

186 See supra Tables 2-5.

187 See Saguato, The Hidden Costs of Clearinghouses, supra note 8 (manuscript at 9-13).

188 See infra notes 210-66 and accompanying text. 
new lines of business at the group level and assuming the presence of an implied public safety net and public backstop. ${ }^{189}$

Yet, do the Dodd-Frank Act and its implemented regulations take into account this new form of agency costs? Do they address the misaligned incentives between clearinghouses and their shareholders? Do clearinghouses, within their authority to self-regulate their internal governance and capital structure, acknowledge and tackle this misalignment of incentives? The next Part of this Article analyzes the existing regulatory framework for derivatives clearinghouses and their internal arrangements in order to assess if and how they address the agency costs that stem from the member-shareholder divide. The Dodd-Frank Act does not address the misaligned incentives between members and shareholders of clearinghouses. In fact, some provisions might even exacerbate these agency costs, and the internal governance arrangements created by clearinghouses might be more aesthetic rather than structural.

\section{THE CURRENT REGULATORY FRAMEWORK AND GOVERNANCE POLICIES FOR CLEARINGHOUSES}

After having analyzed the critical functions that clearinghouses provide to the financial system, as well as the unique agency costs that these firms face, this Part investigates the regulatory framework governing clearinghouses and the ways in which clearinghouses have internalized it. After identifying the foundations of the existing regime, Section IV.A discusses the current regulatory framework for clearinghouses created by Titles VII and VIII of the Dodd-Frank Act. Section IV.B then completes the discussion by looking at how clearinghouses, as self-regulatory organizations, have regulated their internal governance.

189 See Paul Tucker, Speech at the Over-the-Counter Derivatives Symposium: Are Clearing Houses the New Central Banks? 5-6 (Apr. 11, 2014), http://www.chicagofed.org/ /media/others/events/2014/annual-over-thecounter-derivatives-symposium/tucker-clearinghouses-new-central-bankstucker-2014-pdf [https://perma.cc/CC47-QNZC]. 


\section{A. The Current Regulatory Landscape of Clearinghouses}

The derivatives markets were the target of one of the most radical reforms of the post-2008 financial crisis regulatory agenda. ${ }^{190}$ Criticized as one of the catalysts of the crisis, ${ }^{191} \mathrm{de}-$ rivatives markets and the financial institutions operating as dealers underwent a structural makeover. ${ }^{192}$ Policymakers acted on two main objectives: first, to reduce the influence of

190 Not all derivatives markets were targets of the reform. Lawmakers primarily focused on the "swaps markets," which are markets that developed in the late 1990s and boomed throughout the first decade of the 2000s. See generally GILLIAN TETT, FoOL'S Gold (2009).

191 See Alan S. Blinder, After The Music Stopped: The Financial Crisis, The Response, And the Work Ahead 279-80 (2013); Fin. Crisis InQUIRY COMM'N, THE FINANCIAL CRISIS INQUIRY REPORT xxiv-xxv (2011).

192 See, e.g., Viral V. Acharya et al., Regulating OTC Derivatives, in Regulating Wall Street: The Dodd-Frank ACt and the New ArchitecTURE OF GLOBAL FInANCE 367, 370-77 (Viral V. Acharya et al. eds, 2010); J. Christopher Giancarlo, Reconsidering the Dodd-Frank Swaps Trading Regulatory Framework, in REFRAMING FINANCIAL REGULATION: ENHANCING STABility and Protecting Consumers 155, 156-172 (Hester Peirce \& Benjamin Klutsey eds., 2016). This reform wave happened both domestically and internationally, with international financial bodies recommending the deployment of FMIs to stabilize financial markets. At the international level, the Group of Twenty ("G20") and the Financial Stability Board ("the FSB") recommended moving OTC derivatives into centralized and organized markets. See G20, Leaders' Statement: The Pittsburgh Summit 9 (2009), https://www.treasury.gov/resource-center/international/g7-g20/Documents/pittsburgh_summit_leaders_statement_250909.pdf [https://perma.cc/4NLU-QSJ6]; Fin. STABILITY BD., ImPlementing OTC DERIVATIVES MARKET REFORMS 1-2 (2010), http://www.fsb.org/2010/10/fsb-report-on-implementing-otc-derivatives-market-reforms/

[https://perma.cc/J2QT-EWQC]. The international guidelines set by the G20 and the FSB envisioned three pillars to support a more efficient and stable derivatives market: mandatory trading of standardized derivatives in trading venues; mandatory reporting of all derivatives to trade repositories; and mandatory central clearing of eligible derivatives through central counterparties. See Fin. STABILITY BD., supra note 192, at 41-42, 44-49, 29-32. 
dealers in derivatives markets, ${ }^{193}$ and second, to institutionalize the role of clearinghouses as specialized risk managers. ${ }^{194}$

Title VII of Dodd-Frank, the "Wall Street Transparency and Accountability Act," mandated, among other things, the use of clearinghouses for swaps and set general principles for their organization. ${ }^{195}$ Title VIII, entitled "Payment, Clearing, and Settlement Supervision," created a newly enhanced regulatory and supervisory framework for those clearinghouses deemed systemically important by the Financial Market Oversight Council. ${ }^{196}$ The regulatory framework that resulted from these post-crisis reforms is a multi-layered regime in which the Commodity Futures Trading Commission ("the CFTC") 197 and the Securities and Exchange Commission ("the SEC") 198 act as the primary regulators and supervisors of clearinghouses operating in the derivatives and securities markets, ${ }^{199}$ while the Board of Governors of the Federal Reserve System has the authority to adopt heightened prudential regulatory and supervisory standards for systemically important firms in order to promote uniformity and support

193 See Robert E. Litan, The Derivatives Dealers' Club and Derivatives Markets Reform: A Guide for Policy Makers, Citizens and Other INTERESTED PARTIES 29-30 (2010), http://www.brookings.edu/wp-content/uploads/2016/06/0407_derivatives_litan.pdf [https://perma.cc/N92SEZ8Z]; Ferrarini \& Saguato, supra note 57, at 570-71.

194 See Saguato, The Hidden Costs of Clearinghouses, supra note 8 (manuscript at 15-24) (providing an in-depth discussion of the political economy of Title VII and Title VIII of Dodd-Frank).

195 Dodd-Frank Act, Pub. L. No. 111-203, § 723(a), 124 Stat. 1376, 1675-81 (2010) (codified as amended at 7 U.S.C. $§ 2(\mathrm{~h})(8)$ (2018)). See generally Peirce, supra note 9, at 610-20 (offering a comprehensive overview of the current regulatory framework of swap clearinghouses).

196 Dodd-Frank Act $\S \S 805-806$.

197 The CFTC has authority over registered derivatives clearing organizations ("DCOs"). See 7 U.S.C. § 7a-112(h)(8) (2018).

198 The SEC has authority over registered clearing agencies ("CAs"), post-trading services in securities, and securities-based swaps. See DoddFrank Act $§ 763(a)(b)$.

199 In setting risk management standards for systemically important clearinghouses, the CFTC and SEC must consult with FSOC and the Federal Reserve. Id. $\S 805(\mathrm{a})(2)$. 
market resilience and liquidity. ${ }^{200}$ In addition, because of their qualification as self-regulatory organizations, clearinghouses set their own internal rules, as discussed in the next Section.

Because of the critical importance of clearinghouses as systemic risk managers, lawmakers have primarily focused on setting sound prudential requirements and effective risk management and governance standards for these firms. ${ }^{201}$ To support their financial resilience, clearinghouses are required to hold enough resources to cover the losses triggered by the default of their clearing member that presents the largest financial exposure and to cover operational costs for one year. ${ }^{202}$ If a clearinghouse is systemically important, it is required to maintain sufficient financial resources to meet its obligations to its clearing members, notwithstanding the default of its two clearing members with the largest combined financial exposure to the clearinghouse (this requirement is referred to as the "Cover 2" standard). ${ }^{203}$

Furthermore, clearinghouses are required to develop public rules and procedures for the "efficient, fair, and safe"

$200 I d . \S 805(\mathrm{a})(2)(\mathrm{B})$. The Federal Reserve can determine that the existing prudential requirement set by the CFTC and SEC for systemically important or "covered" clearinghouses "are insufficient to prevent or mitigate significant liquidity, credit, operational, or other risks to the financial markets or to the financial stability of the United States" and in that situation FSOC is the ultimate arbiter as to which risk management standard should apply. Id. $\S \S 805(\mathrm{a})(2)(\mathrm{B})-(\mathrm{D})$. Dodd-Frank Title VIII grants clearinghouses designated as "systemically important" the option to have a Federal Reserve account in "unusual or exigent circumstances." Id. § 806(b).

201 For an elaborate discussion of the post-crisis reform of the derivatives markets, see Saguato, The Hidden Costs of Clearinghouses, supra note 8 (manuscript at 9-15).

202 Dodd-Frank Act $\S 725(c)$.

203 See Financial Resources Requirements for Systemically Important Derivatives Clearing Organizations and Subpart C Derivatives Clearing Organizations, 17 C.F.R. § 39.33(a) (2019) (for systemically important DCOs); Standards for Clearing Agencies, 17 C.F.R. § 240.17Ad-22(b)(3) (2019) (for systemically important CAs). The baseline regime for DCOs and CAs requires that firms maintain resources sufficient to cover the default of the member with the largest exposure. See Financial Resources, 17 C.F.R. $\S 39.11$ (a) (2019) (for DCOs); 17 C.F.R. § 240.17Ad-22(b)(3) (2019) (for CAs). 
management of the default of one of their members, ${ }^{204}$ and to plan recovery mechanisms for severe distress scenarios. ${ }^{205}$ Different varieties of resources are available for clearinghouses to use in order to build their capital buffer. ${ }^{206}$ A clearinghouse shall maintain "additional prefunded financial resources that are sufficient to cover its credit exposure under a wide range of significantly different stress scenarios," which include the default of one or two of its participants with the largest aggregate credit exposure to the clearinghouse. ${ }^{207} \mathrm{~A}$ clearinghouse has to be regularly subjected to supervisory stress tests of its resources. ${ }^{208}$

From a governance and risk management perspective, clearinghouses shall ensure that their "governing board or committees" include market participants. ${ }^{209}$ Ample discretion is left to clearinghouses to determine the amount of market participants included on their governing committees. However, their governance arrangement must be transparent in order "to fulfill public interest requirements [and] to permit the consideration of the views of owners and participants." 210 Clearinghouses must have in place a comprehensive risk management framework to deal with the legal, credit, liquidity, operational, and other risks that might arise from its business. ${ }^{211}$ Clearinghouses are required to effectively measure, monitor, and manage the credit exposure of their members and participants. ${ }^{212}$ Yet, both the law and applicable regulations are silent on whether a clearinghouse should have in

204 Dodd-Frank Act $\S 725(c)$. See also Risk Management, 17 C.F.R. $\S$ 39.13 (2019).

205 Dodd-Frank Act $\S 725(c)$; System Safeguards, 17 C.F.R. $§ 39.18$ (2019).

206 See 17 C.F.R. § 39.11(b).

207 Standards for Payment Systems, 12 C.F.R. § 234.3(a)(4)(i) (2019).

208 See 17 C.F.R. $§ 39.11$; Financial Resources Requirements for Systemically Important Derivatives Clearing Organizations and subpart C Derivatives Clearing Organizations, 17 C.F.R. $\$ 39.33$ (2014).

2097 U.S.C. $\S 7 \mathrm{a}-1(\mathrm{c})(2)(\mathrm{Q})(2018)$.

$210 I d . \S 7 \mathrm{a}-1(\mathrm{c})(2)(\mathrm{O})(\mathrm{i})$.

211 See Saguato, The Ownership of Clearinghouses, supra note 8, at 619-23.

212 See id. 
place a specific governance structure or specific committees designated for the oversight of the firm's risk management. As is more fully described in the next Section, in practice, clearinghouses in their capacity as self-regulatory organizations have all created comprehensive and sound risk management procedures, establishing risk committees responsible for advising and supervising the risk management activities of the firm. While moving in the right direction, however, these structures lack effective checks and balances. These committees have a mere consultative role, with no binding power over the board of directors or access to any procedure that can increase the accountability and transparency of a board that dissents from the committee's determination. ${ }^{213}$ This situation potentially polarizes the incentives of members and shareholders. While the law regarding the regulation of clearinghouses has a very gentle touch in setting governance and risk management standards, embracing a high-level, principlesbased approach that leaves wide discretion to the industry, ${ }^{214}$ Dodd-Frank took a very clear and strict approach in regulating the conflicts of interest that, according to its drafters, could threaten the systemic resilience of clearinghousesnamely, the influence of derivatives dealers (i.e., the members) over the firm. ${ }^{215}$ Clearing members, despite being required to substantially support the systemic financial resilience of clearinghouses, are restricted in terms of their voting rights and control (i.e., the types of shares they can own or beneficial interests they can build), ${ }^{216}$ and are not given any

213 See ICE Clear Credit, supra note 141.

214 See, e.g., Governance, 17 C.F.R. $\$ 39.24$ (2019); Composition of Governing Boards, 17 C.F.R. § 39.26 (2019).

215 For a comprehensive discussion of the political economy of Title VII and VIII of Dodd-Frank, see Saguato, The Hidden Costs of Clearinghouses, supra note 8 (manuscript at 17-24).

216 Ownership Limitations and Governance Requirements for Security-Based Swap Clearing Agencies, Security-Based Swap Execution Facilities, and National Securities Exchanges With Respect to Security-Based Swaps Under Regulation MC, 75 Fed. Reg. 65,882 (proposed Oct. 26, 2010) (to be codified at 17 C.F.R. pt. 242). The SEC and CFTC, in implementing the legislative mandate of Dodd-Frank proposed rules to tackle what lawmakers defined as the "conflicts of interest in connection with the conduct 
formal right of participation in the governance of firms' risk management. ${ }^{217}$ Ten years after the passage of Dodd-Frank, both the CFTC and SEC proposed rules to directly address the internal accountability and corporate governance structure of clearinghouses. ${ }^{218}$ While framed as rules that would mitigate potential conflicts of interest within clearinghouses and promote competition in the clearing market, ${ }^{219}$ if adopted, these rules could drastically reduce the accountability of clearinghouses to their members and further misalign the incentives of the firms' main stakeholders. ${ }^{220}$ These proposed rules (1)

of business by a swap dealer or a major swap participant with a derivative clearing organization.” Dodd-Frank Act $§ \S 725(d), 726$, 765; Requirements for Derivatives Clearing Organizations, Designated Contract Markets, and Swap Execution Facilities Regarding the Mitigation of Conflicts of Interest, 75 Fed. Reg. 63,732 (proposed Oct. 18, 2010) (to be codified at 17 C.F.R. pts. 1, 37-40); Governance Requirements for Derivatives Clearing Organizations, Designated Contract Markets, and Swap Execution Facilities; Additional Requirements Regarding the Mitigation of Conflicts of Interest, 76 Fed. Reg. 722 (proposed Jan. 6, 2011) (to be codified at 17 C.F.R. pts. 1, 3740). Ten years after their adoption, these proposed rules have not been yet implemented. See Governance \& Conflicts of Interest, COMMODITY FUTURES TRADING Commission, https://www.cftc.gov/LawRegulation/DoddFrankAct/Rulemakings/DF_9_DCOGovernance/index.htm [https://perma.cc/H63P-CUC2] (last visited July 1, 2020).

217 See Saguato, The Ownership of Clearinghouses, supra note 8, at 655-56. For criticisms of the governance regime introduced by Dodd-Frank, see Peirce, supra note 9, at 655 (defining the control restrictions set by the Dodd-Frank Act as "ill-considered"); Griffith, supra note 9, at 1218-26 (offering a solid critique of the governance lines proposed by regulators for clearinghouses-ownership and voting caps and independence requirements-defining them as "misguided" and "likely to [not] be effective in ... the effective containment of systemic risk").

218 Requirements for Derivatives Clearing Organizations, Designated Contract Markets, and Swap Execution Facilities Regarding the Mitigation of Conflicts of Interest, 75 Fed. Reg. at 63,732; Governance Requirements for Derivatives Clearing Organizations, Designated Contract Markets, and Swap Execution Facilities; Additional Requirements Regarding the Mitigation of Conflicts of Interest, 76 Fed. Reg. at 722.

219 Dodd-Frank Act $\S \S 726(\mathrm{~b}), 765(\mathrm{~b})$.

220 See Adam J Levitin, Prioritization and Mutualization: Clearinghouses and the Redundancy of the Bankruptcy Safe Harbors, 10 BRoOK. J. CoRP. FIn. \& CoM. L. 129, 153 (2015) (acknowledging as a major regulatory task the creation of a prudential regulatory system for clearinghouses that prioritizes risk management over the expansion of market share). 
cap the control and voting rights of investors and members of derivatives clearing organizations ("DCOs") and clearing agencies ("CAs"); ${ }^{221}$ (2) define public (i.e., independent) directors in a very narrow way that excludes directors with a material relationship to clearing members;222 (3) require a substantial (35\%) representation of public members on clearinghouses' boards of directors and on critical committees (e.g., the nomination committee, risk committee, etc.); ${ }^{223}$ and (4) define the roles and competencies of the risk committee. ${ }^{224}$

This principles-based approach adopted by regulators gives clearinghouses vast authority over their internal governance. The next Section offers a comprehensive survey of the governance arrangements adopted by the systemically important firms operating in the securities and derivatives markets.

221 Requirements for Derivatives Clearing Organizations, Designated Contract Markets, and Swap Execution Facilities Regarding the Mitigation of Conflicts of Interest, 75 Fed. Reg. at 63,733; Governance Requirements for Derivatives Clearing Organizations, Designated Contract Markets, and Swap Execution Facilities; Additional Requirements Regarding the Mitigation of Conflicts of Interest, 76 Fed. Reg. at 722-23 n.8.

222 See Requirements for Derivatives Clearing Organizations, Designated Contract Markets, and Swap Execution Facilities Regarding the Mitigation of Conflicts of Interest, 75 Fed. Reg. at 63,742; Definitions, 17 C.F.R. $\S 1.3(\mathrm{c})(2019)$.

223 Requirements for Derivatives Clearing Organizations, Designated Contract Markets, and Swap Execution Facilities Regarding the Mitigation of Conflicts of Interest, 75 Fed. Reg. at 63,740. The CFTC, for example, requires clearinghouses to have a risk management committee in place, of which at least thirty-five percent of the -member-directors are public or independent-i.e., with no ties with clearing members-and at least ten percent represent end-users. See id. The risk management committee is responsible for, among other things, advising the board of directors on risk models and the clearinghouse's default procedure; determining the standards and requirements for initial and continuing clearing membership eligibility; approving or denying membership applications; and determining the products eligible for clearing. See id. at 63,740-41.

224 See id. at 63,750. 


\section{B. The Internal Governance of Clearinghouses: An Industry Overview}

Overall, U.S. clearinghouses all operate with the same economic structure and default waterfall. However, they differ in their allocation of control rights. All clearinghouses rely on a guaranty fund or clearing fund to provide a loss-sharing function; in all of the firms previously analyzed, the clearing members or participants contribute to that fund. ${ }^{225}$ However, clearinghouses vary greatly in their allocation of ownership and control rights, differently addressing the costs that might arise from the separation of control and final risk-bearing costs.

In the securities markets, post-trading services are provided by standalone specialized firms that offer their services horizontally to multiple trading platforms without being a subsidiary of any exchange (trading) group. The DTCC Group, along with its subsidiaries, provides clearing and settlement services for the U.S. securities markets. ${ }^{226}$ DTCC is the result of the consolidation of all securities clearinghouses, begun after the "paperwork crisis" of the 1970s. ${ }^{227}$ The ownership and governance structure of DTCC preemptively addresses the potential costs associated with the risk mutualization function of the clearing fund by having clearing members as shareholders of the firm and assigning representatives of the clearing members control and monitoring rights over the clearing

225 See infra Tables 2-5.

226 See NoRMAN, supra note 15, at 169-74; see also DTCC's Businesses, Subsidiaries and Joint Ventures, Depository Tr. \& Clearing CorP., https://www.dtcc.com/about/businesses-and-subsidiaries

[https://perma.cc/RPM6-P7EY] (last visited May 14, 2020) (describing DTCC group's structure).

227 The "paperwork crisis" revealed that the paper-based and fragmented back-office activities of stock exchanges and their clearinghouses were inadequate and unable to keep pace with the growing volume of executed and cleared contracts. See Norman, supra note 15, at 170. Further, the 1975 Securities Act Amendments induced the major stock exchanges to spin-off their clearinghouses and merge them into a single firm: the National Securities Clearing Corporation ("NSCC"), which is the largest pillar of DTCC. See Norman, supra at 15, at 123-26. 
firms. ${ }^{228}$ In all DTCC clearinghouses, member-shareholders have full skin-in-the-game, both as equity capital providers and guaranty fund contributors. ${ }^{229}$ The DTCC Group is a member (user) owned and governed firm. ${ }^{230}$ DTCC's common shareholders are the financial institutions that are participants and members of the subsidiaries' post-trading businesses and are allocated an amount of shares that reflects their usage of the post-trading services of all of the Group's firms. ${ }^{231}$ Buying into the equity capital of DTCC and agreeing to become a party of the shareholder agreement that binds all existing DTCC shareholders are the necessary conditions for becoming a member of the National Securities Clearing Corporation ("the NSCC") and the Fixed Income Clearing Corporation ("the FICC"), the two systemically important clearinghouses of the Group. ${ }^{232}$

Member-shareholders elect DTCC's board of directors. ${ }^{233}$ DTCC directors are then also appointed to the boards of directors of the NSCC and the FICC. ${ }^{234}$ The DTCC board charter acknowledges the critical role that member-shareholders play in the clearing business, noting that "by virtue of making

228 See Depository Tr. \& Clearing CoRP., CCP RESILIENCY AND RESOURCES 2 (2015), http://www.dtcc.com/news/2015/june/01/ccp-resiliencyand-resources [https://perma.cc/A524-JKQU].

229 See id. at $4-5$.

230 See id. at 2; see also NAT'L SEc. Clearing Corp., Disclosure FrameWORK FOR COVERED CLEARING AGENCIES AND FINANCIAL MARKET INFRASTRUCTURES 24 (2020) [hereinafter NSCC Disclosure Framework], https://www.dtcc.com/legal/policy-and-compliance [https://perma.cc/8NU387GM].

231 See NSCC Disclosure Framework, supra note 230, at 24.

232 See Nat'l Sec. Clearing Corp., Rules \& Procedures 211 (2020); Fixed Income Clearing Corp., Government Securities Division RuleBOOK 267 (2020).

233 See BD. of Dirs., Depository Tr. \& Clearing Corp., Mission StATEMENT AND CHARTER 5 (2020) [hereinafter DTCC BOARD Mission AND CHARTER].

234 Fixed Income Clearing Corp., Disclosure Framework for Covered Clearing Agencies and Financial Market Infrastructures 28 (2020) [hereinafter FICC DisCLOSURE FRAMEWORK], https://www.dtcc.com//media/Files/Downloads/legal/policy-and-compliance/FICC_Disclosure_Framework.pdf [https://perma.cc/C8A4-JA42]; NSCC DiscLOSURE FRAMEWORK, supra note 230, at 24. 
deposits to a clearing fund or otherwise, [member-shareholders] share the risk of loss associated with settlement defaults or other clearing agency losses." 235 In addition, the Securities Exchange Act requires the board to have a "fair representation" of the firm's participant shareholders. ${ }^{236}$ The board is composed of twenty-one members: fourteen of the directors represent clearing members ("participant directors"); three are non-participant ("independent) directors; two represent the two preferred shareholders (the Intercontinental Exchange) and the Financial Industry Regulatory Authoritythe securities market's private self-regulators); and the remaining two seats are the Non-Executive Chairman of DTCC and its President and Chief Executive Officer. ${ }^{237}$ Within the board's perimeter, the risk committee is the most important actor: it supports the board in fulfilling its duty to oversee the risk management activities of DTCC and its subsidiaries. ${ }^{238}$ Reflecting the allocation of the risk of losses in the clearing business, the firm's risk committee is dominated by membershareholders: it is currently composed of nine members, seven of whom represent clearing members and two of whom, including the committee Chairman, are independent from clearing participant members. ${ }^{239}$ Subject to the direction of the board, "the Committee's role is one of oversight." 240 The risk

235 DTCC BOARD Mission AND CHARTER, supra note 233, at 6.

236 See Securities Exchange Act of 1934 § 17A, 15 U.S.C. § 78q1(b)(3)(C) (2018). The Board charter also states that the firm "serves a broad range of constituencies including DTCC shareholders, its financial institution participants, their issuer and investor clients and the governmental and supervisory authorities responsible for the global clearance and settlement systems." DTCC BOARD MISSION AND CHARTER, supra note 233, at 6 .

237 See The DTCC Board, Depository TR. \& Clearing Corp., https://www.dtcc.com/about/leadership [https://perma.cc/7WKP-DCX5] (last visited May 14, 2020); DTCC BOARD MISSION AND CHARTER, supra note 233 , at 5-6. Of the twenty-one DTCC directors, fourteen are elected by the clearing members. See The DTCC Board, supra note 237.

238 Depository Tr. \& Clearing Corp., Risk Committee Charter 1 (2020) [hereinafter DTCC Risk CoMmitTeE CHARTER].

239 Id. at 2; Board Committees, Depository Tr. \& Clearing Corp., https://www.dtcc.com/about/leadership/committees [https://perma.cc/H3RG-ZS9M] (last visited May 14, 2020).

240 DTCC Risk CommitTee Charter, supra note 238, at 3-4. 
committee is responsible for the firm's risk framework; it approves risk management processes and procedures and oversees the clearing firm's safety and soundness by monitoring the management of risk-related activities and advising on risk management-related matters. ${ }^{241}$ In its tasks, the risk committee is supported by the management risk committee, which is responsible for monitoring and overseeing the company's management of its day-to-day credit, liquidity, market, operational, and systemic risks. ${ }^{242}$

Standing between member-owned and investor-owned clearinghouses is the OCC, the largest provider of clearing services for equity derivatives. ${ }^{243}$ The OCC has a unique ownership structure: ${ }^{244}$ the firm is owned by five equity exchanges for which it provides clearing services. ${ }^{245}$ Ownership is

241 Id. at $4-8$.

242 Id. at 1-2.

243 See Options Clearing Corp., Clear The Path: 2018 Annual RePORT 2 (2019), https://www.theocc.com/components/docs/about/annual-reports/occ-2018-annual-report.pdf [https://perma.cc/XM94-D38B].

244 Id. at 36-37, 46 (discussing the ownership structure of the OCC and a proposed but rejected capital plan that would have provided the OCC with new capital contributions by its shareholders). Craig Donohue, CEO of the only U.S. options clearinghouse, has clashed with traders over his proposed capital plan. See Gunjan Banerji, A Messy Battle Brews in the Options Market, WALL ST. J. (Aug. 22, 2018), https://www.wsj.com/articles/a-messy-battle-brews-in-the-options-market-1534939201] [https://perma.cc/QA3YVZTF]. The rejection of Donohue's recent proposal is the latest development in a yearlong dispute, creating fresh uncertainty for an organization vital to the options market. See Gunjan Banerji, SEC Rejects Capital Plan by Options Clearinghouse, WALL ST. J. (Feb. 13, 2019), https://www.wsj.com/articles/sec-rejects-capital-plan-by-options-clearinghouse- 11550107475 [https://perma.cc/NX6A-9KE7].

245 Options Clearing Corp., The Options Clearing Corporation DisClosure FramewORK FOR FinANCIAL MARKETS InFRASTRUCTURES 5 n.3 (2020), https://www.theocc.com/components/docs/risk-management/pfmidisclosures.pdf [https://perma.cc/7XTY-ZL2N] ("The five owners are the Chicago Board Options Exchange, Inc., International Securities Exchange LLC, NASDAQ OMX PHLX LLC, NYSE MKT LLC, and NYSE Arca, Inc. The NYSE exchanges are owned by a common parent and the International Securities Exchange is owned by NASDAQ. As a result, ownership is essentially consolidated to three entities although each Equity Exchange has one Exchange Director representative on the Board.”). 
restricted to qualified equity exchanges, ${ }^{246}$ and transferability of shares is limited to either existing shareholders ${ }^{247}$ or to current non-shareholders that meet the equity exchange qualification criteria set by the firm's bylaws. ${ }^{248}$ The OCC, while owned by exchanges, relies on clearing members for contributions and gives them a central role in the governance of the board. The board of directors has a multi-stakeholder structure dominated by clearing members and independent directors (i.e., end-users). ${ }^{249}$ Of the twenty directors, five represent the five owners' exchanges ("exchange directors"); nine are designated by the clearing members ("member directors"); five are appointed as "public directors" (who must not be affiliated with any national securities exchange, securities association, or any broker or dealer in securities); and one, the "management director," is an inside director chosen from the employees of the firm-the current employees of the OCC chose the Executive Chairman of the firm to be the management director elected on the board. ${ }^{250} \mathrm{As}$ is true for all clearinghouses, the OCC's risk committee-composed of the Executive Chairman and at least one management director, one public director, and one exchange director-plays an important part in the oversight of the firm's risk management processes and mechanisms. ${ }^{251}$ The risk committee reviews, has the authority to amend, and eventually recommends to the board the adequacy of the firm's counterparty, collateral, and liquidity risk policies. ${ }^{252}$ It oversees risk models, recovery and resolution plans, and the clearing membership and financial safeguard frameworks. ${ }^{253}$ For all of these matters, the risk committee has the authority to make non-binding recommendations to

246 Options Clearing CorP., By-LaWs art. I.E, § 6 (2019).

247 Id. art. VIIA $\S 2$.

$248 I d . \S \S 1-2$.

249 See Options Clearing CoRP., supra note 245, at 16-33.

250 See BD. Of Dirs., Options Clearing Corp., Charter and CorpoRAte Governance Principles 4 (2019).

251 See Options Clearing CoRP., Risk Committee Charter 1 (2019).

252 Id. at $2-3$.

253 See id. at $4-8$. 
the board; however, the committee has final authority in approaching prospective clearing members' applications. ${ }^{254}$

The derivatives clearing markets, on the other hand, are structurally different. FMIs have developed into vertically integrated (open or partially open) ${ }^{255}$ silos, ${ }^{256}$ where clearinghouses are investor-owned firms, subsidiaries, or business units of a trading platform or a large for-profit public holding corporation listed on a stock exchange. ${ }^{257}$ Both of the largest derivative clearinghouses operating in the U.S. are parts of large infrastructural groups, where trading, post-trading, and informational services are provided in a vertical structure..$^{258}$ They also transitioned, at some point in the last twenty years, from being owned by their members or by a mutual exchange to being investor-owned (or, more precisely, owned by a demutualized and investor-owned trading platform or holding company). ${ }^{259}$

The Chicago Mercantile Exchange Inc.(“CME Inc.”) and its clearing division ("CME Clearing"), ${ }^{260}$ are part of the CME

254 See OPTIONS ClEARING CORP., supra note 245, at 97-98, 105-06.

255 The Dodd-Frank Act required open access to clearing services for swaps and securities-swaps regulated by both the CFTC and the SEC. See Dodd-Frank Act, Pub. L. No. 111-203, §§ 723(a)(3), 763, 124 Stat. 1376, 1675, 1762 (2010). See also General Rules and Regulations, Securities Exchange Act of 1934, 17 C.F.R. $§ 240$ (2012).

256 See e.g., CME Group Overview, supra note 140; ICE Clear Credit, supra note 141.

257 For instance, CME Group is listed on Nasdaq. See CME Group Inc. Class A Common Stock (CME), supra note 142. The Intercontinental Exchange is listed on the New York Stock Exchange. See Intercontinental Exchange Inc. ICE, supra note 142. See also NoRMAN, supra note 15, at 197210, 268-72 (providing a historical discussion of the evolution of CME and describing the creation of ICE).

258 See Saguato, The Ownership of Clearinghouses, supra note 8, at 612 tbl. 1. See also Ferrarini \& Saguato, supra note 16, at 299-308 (analyzing the characteristics of financial market infrastructural groups).

259 See Saguato, The Ownership of Clearinghouses, supra note 8, at 625-26.

260 CME Inc. is one of the four exchanges of the CME Group Inc. See About CME Group, CME GROUP, https://www.cmegroup.com/company/ [https://perma.cc/FHV8-89ST] (last visited July 1, 2020). CME Clear clears both exchange-traded and OTC derivatives. See What is Clearing, CME 
Group, which, along with ICE Clear Credit ("ICC"), a subsidiary of the Intercontinental Exchange Group, ${ }^{261}$ are the systemically important clearinghouses operating in the U.S. derivatives markets. ${ }^{262}$ Being (indirectly) a wholly-owned subsidiary of a listed corporation, in the case of ICC, 263 or a business unit and internal division of a subsidiary of a listed corporation, in the case of CME Clearing, ${ }^{264}$ makes the governance arrangement and the alignment of incentives between clearing members and firm shareholders particularly interesting.

CME Inc.'s "Board of Directors . . is comprised of the same individuals as the Board of Directors of CME Group."265 The firm acknowledges its two potentially conflicting purposes: on the one hand, as a private corporation, CME Inc. is committed to maximizing shareholder value; on the other, having been entrusted with a systemic stability function, CME Inc. is aware of its role in providing safe and sound clearing operations for the derivatives markets. ${ }^{266}$ In this direction, CME Clearing established structural and procedural safeguards to fulfill its "governance and oversight responsibility of the safety and efficiency of CME Clearing."267 CME Clearing's board of directors is comprised of a majority of independent

GROUP, https://www.cmegroup.com/education/courses/clearing/what-isclearing.html [https://perma.cc/XDB9-ELB9] (last visited May 14, 2020).

261 See ICE CLEAR CREDIT LLC, supra note 169, at 6.

262 See FSOC REPORT, supra note 144, at 144.

263 ICE Clear Credit is wholly owned by ICE US Holding Company L.P. ("ICC Parent"), which is owned by ICE US Holding Company GP LLC and ultimately by Intercontinental Exchange, Inc. See ICE CleAr CREDIT LLC, supra note 169 , at 6 .

264 See CME Group, Clearing Membership Handbook 1-1 (2018), https://www.cmegroup.com/company/membership/files/cme-group-clearingmembership-handbook.pdf [https://perma.cc/9AH5-4GTP].

265 See CME Group, CME Clearing: Principles for Financial MarKET INFRASTRUCTURES Disclosure 14 (2019) [hereinafter CME CleARING PRINCIPLES], https://www.cmegroup.com/clearing/risk-management/files/cme-clearing-principles-for-financial-market-infrastructuresdisclosure.pdf [https://perma.cc/EMC3-9XC8].

266 Id. at 15.

267 Id. 
directors. ${ }^{268}$ In order to more effectively perform its oversight duties in the clearing business, it established three main committees: the clearing house oversight committee, ${ }^{269}$ the risk committee, ${ }^{270}$ and the CME clearing risk committee ${ }^{271}$ These committees, working closely with the senior management of CME Clearing, have been tasked, in different ways, with overseeing and advising the board on different facets of the clearinghouse's risk management programs and mechanisms. ${ }^{272}$ CME Clearing acknowledges the importance of providing accountability to its main constituencies and key market stakeholders. CME Clearing, through governance arrangements, is committed to considering the legitimate interests of its clearing members and its end-users, and has agreed to have the majority of its board members be representatives from market participants. $^{273}$

268 See BD. of Dirs., CME Group, Corporate Governance Principles $2(2020)$.

269 See CME Clearing Principles, supra note 265, at 4. The Clearing House Oversight Committee "is comprised entirely of Board members, works cohesively with the full Board in advising it on its oversight of the risk management activities of the Clearing House, including the effectiveness of CME Clearing's risk management program." CME GROUP, supra note 268, at 19. Among its responsibilities are the firm's financial safeguards waterfall (i.e., its lines of defense against risk); the revision and adoption of methods to calculate the guaranty fund, and any other change to the clearing business that might affect the risk profile of the firm; and reviewing membership requests. Id.; see also CHI. Mercantile Exch. Inc., Clearing House Oversight Committee Charter 2-3 (2019).

270 See CME Clearing PRInciPles, supra note 265, at 4. See also CME Clearing PrinciPles, supra note 265, at 19 ("The Board Risk Committee, which is comprised entirely of Board members, is tasked with overseeing CME Group's risk management practices and to assist the Board in its oversight of the effectiveness of the CME Group's policies and processes to identify, manage, and plan for its clearing house, compliance, financial, operational, reputational, and strategic and commercial risks . ...”).

271 See CME Clearing PRINCIPLEs, supra note 265, at 4. The CME Clearing Risk Committees are the Clearing House Risk Committee and IRS Risk Committee. See CME Clearing Principles, supra note 265, at 20-21.

272 See CME Clearing Principles, supra note 265, at 20-21.

273 See CME Group Inc. ET AL., Corporate governance Principles 2-4 (2020), http://investor.cmegroup.com/static-files/3ae051c4-0d94-4fcdb09d-11601c027286 [https://perma.cc/3GDZ-T24W]. 
A final note on the governance of CME Clearing: the firm's corporate governance principles recognize the importance of having an outside, independent director sitting on the board and expressly states that a director who is an employee or officer of a clearing member is presumed to be independent if all other independence requirements are met. ${ }^{274}$ Despite this important provision, which has the potential to advance a multistakeholder governance model for demutualized clearinghouses, only two of the twenty-three directors currently represent clearing members, ${ }^{275}$ and only one of them clears interest rate swaps. ${ }^{276}$

The governance and risk management structure of the other investor-owned clearinghouse, ICC, is not substantially dissimilar from that of CME Clearing. ${ }^{277}$ Independent directors (i.e., managers) make up the majority of the eleven members of ICC's board of managers. ${ }^{278}$ Three members are part of the senior management team of the holding company, ICE; four are independent members; and four are designated by ICC's risk committee for election by ICE— two of whom must be independent and two of whom may be non-independent. ${ }^{279}$ Of the eleven directors, only two represent clearing members. ${ }^{280}$ Clearing members, on the other hand, have strong

274 See CME ClEARING PRINCIPLES, supra note 265.

275 See Board of Directors, CME GROUP, http://investor.cmegroup.com/board-of-the-directors [https://perma.cc/MME2-KUNX] (last visited May 14, 2020).

276 The only member of the Board who represent a swap clearing member is Mr. Michael G. Dennis, who is Principal and Chief Commercial Officer ABN AMRO Clearing Chicago LLC. See Michael G. Dennis, CME Group, http://investor.cmegroup.com/board-directors/michael-dennis [https://perma.cc/XKM8-5JMU] (last visited July 1, 2020); see also Clearing Firms, CME GrouP, https://www.cmegroup.com/clearing/financial-and-regulatory-surveillance/clearing-firms.html [https://perma.cc/4SBG-7YR5] (last visited May 15, 2020).

277 See Guseva, supra note 9, at 1758-59.

278 ICE CLEAR CREDIT, supra note 158, at 3.

279 See id.

280 See id. The two Board members representing clearing participants are Biswarup Chatterjee (Global Head of Electronic Trading and Distribution, Credit Markets at Citigroup) and Amy Hong (Managing Director and Global Head of Market Structure Strategy, Goldman Sachs). Id. See also Ice 
representation on the risk committee: a majority of its members are in fact representatives of clearing members, ${ }^{281}$ as the firm recognizes the necessity of having a strong representation of clearing participants "because of the risk mutualization function of [the] clearing house" and because clearing members bear the tail risk of the default of peer members. ${ }^{282}$ The board of managers is required to consult with the risk committee on any matter related to risk management policies and standards-i.e., margin, product clearing, guaranty fund contributions, membership qualifications, amendment to the rulebook, etc. ${ }^{283}$ Nevertheless, the firm's rulebook expressly states that the role of the risk committee is primarily an advisory and consultative one, ${ }^{284}$ and the board of members of ICC is by no means bound to the determinations of the risk committee. ${ }^{285}$

Clear Credit: Participants, InTERCONTINENTAL ExCHANGE, https://www.theice.com/clear-credit/participants [https://perma.cc/XWT8CKF5] (last visited May 15, 2020).

281 See ICE CLEAR CREDIT, supra note 158, at 3.

282 See id. Of the twelve members, nine represent the clearing members and "[t]he three additional Risk Committee members include two members of ICE Clear Credit management and an independent member of the ICE Clear Credit Board of Managers, who serves as chairman." Id.

283 See id. at 3.

284 See id.

285 See ICE Clear CRedit, Clearing Rules, supra note 25, at 65-76 (analyzing the regime of the Risk Committee). Rule 501 expressly states that:

[n]otwithstanding anything to the contrary in these Rules, the Board shall not have any obligation to accept any proposal made by, or take any action proposed by, the Risk Committee, and any deliberation and/or decision by the Board with respect to any such proposal shall be made at the sole discretion of the Board, with no obligation whatsoever to the Risk Committee in respect of such deliberation or decision.

Id. at 65 . 


\section{HOW TO IMPROVE CLEARINGHOUSE RESILIENCE: GOVERNANCE AND CAPITAL REGULATION}

The analysis until this point has shown that clearinghouses are central to the modern financial system and that the clearing market ecosystem has developed around two different organizational models. These are member-owned clearinghouses with mutual ownership and mutualization of risk, where the shareholders of the firm are the clearing members, and investor-owned clearinghouses, with demutualized ownership in the hands of equity investors and mutualization of risk among clearing members (who are prevented by law from gaining control of clearinghouses). In the aftermath of the 2008 financial crisis, lawmakers have relied on clearinghouses as systemic risk managers and stability buffers, and have implemented regulations to discipline them. However, when drafting the new regulatory regime for clearinghouses, policymakers did not take into account the different ownership structures of these firms and did not consider the misaligned incentives and agency costs that investor-owned clearinghouses can create by polarizing the economic exposures and control rights of their two main stakeholders: members and shareholders. On the one hand, clearinghouse shareholders could motivate firms to take on additional marginal risk in order to increase profits-for instance, by increasing clearing fees, increasing clearing volume by reducing margin requirements, ${ }^{286}$ opening up membership requirements, or accepting more volatile and risky clearable derivatives. On the other hand, members have an interest in clearinghouses being bastions of financial stability with effective and robust risk management mechanisms, to reduce the likelihood that they will bear the cost of the default of one of their peer members.

286 See Faruqui et al., supra note 3, at 75-76 (questioning why Nasdaq Clearing AB's margin requirements of its defaulted member were insufficient to substantially cover the risk of his portfolio; a possible explanation can be found in competitive pressures or search for trade volume-i.e., more fees). 
The existing regulatory regime and the internal governance agreements adopted by clearinghouses are vulnerable to the same critiques. The lack of meaningful representation of clearing members at the board level and in the firms' risk committees, the absence of minimum capital requirements for clearinghouses' skin-in-the-game, and the restrictions on members' rights in the governance of risk all undermine clearinghouses' accountability and potentially exacerbate firms' moral hazard-exposing them to risk-taking behaviors, incentivizing the externalization of losses and risk on members, and in the end, threatening the stability of financial markets. Put differently, lawmakers used clearinghouses to shift systemic risk from the markets to specialized risk managers and risk absorbers. Cognizant of the concentration of risk in a few institutions, following the financial crisis regulators drafted internal governance and risk management regulations to reduce the influence of derivatives dealers and tackled what were deemed to be the troubling conflicts of interest in clearinghouses. ${ }^{287}$ However, the operation of the new regulatory framework within the context of for-profit financial market infrastructural groups has resulted in a dangerous allocation of risk-taking incentives and control rights between clearinghouses' main stakeholders, who mine the systemic resilience of these firms. Ultimately, the current regime has turned systemic risk managers and risk absorbers into super-systemic firms - which, if not properly regulated and organized, could become systemic risk transmitters, amplifiers, and threats. ${ }^{288}$

This Part contributes to a long overdue but finally reopened policy discussion on how to achieve and support clearinghouses' systemic resilience. ${ }^{289}$ In a previous article, I

287 See Greenberger, supra note 9, at 263-68. See also supra notes 222 20 and accompanying text.

288 See Letter from Sir Paul Tucker, Chair, Systemic Risk Council, to the Hon. Randal K. Quarles, Chair, Fin. Stability Bd. 1 (Mar. 18, 2019), https://www.systemicriskcouncil.org/2019/03/systemic-risk-council-urgesaction-on-resolution-of-central-counterparty-clearing-houses/ [https://perma.cc/5K7L-2GFY].

289 See Fin. Stability BD., Financial Resources to Support CCP RESOLUTion AND THE TREATMENT OF CCP EQUity IN RESOLUTion (2018), http://www.fsb.org/wp-content/uploads/P151118-2.pdf 
discussed the historical evolution of clearinghouses and focused on the role of ownership structures as a mechanism to align the incentives and economic interests of firms' stakeholders. ${ }^{290}$ That article's main normative claim was that the remutualization of clearinghouses is the optimal solution to resolve the agency costs that spill from the member-shareholders divide. ${ }^{291}$ However, acknowledging the political and market costs of implementing such reforms, that article proposed two less invasive policy solutions that focus on the capital structure and governance of clearinghouses. ${ }^{292}$ This Part builds upon that policy discussion by offering some new and refined solutions to the agency costs that result from the decoupling of risk from control rights in clearinghouses. Multistakeholder boards and member-driven risk committees would more effectively represent the interests and positions of clearinghouses' main constituencies: those members that have full skin-in-the-game in the business. ${ }^{293}$ Direct intervention into the capital structure of clearinghouses-and into the type and quality of financial instruments that these firms should issue to build their capital buffers-would stabilize their financial resilience. This Part then concludes by offering some preliminary considerations on the dynamics of the recovery and resolution mechanisms of clearinghouses, a critical gap in the post-crisis regime. ${ }^{294}$

\section{A. Existing Academic Proposals}

Few legal scholars have examined the organization of clearinghouses and its consequences in terms of firms'

[https://perma.cc/QJ3Z-MFT8]; Derivatives Clearing Organization General Provisions and Core Principles, 84 Fed. Reg. 22,226 (proposed May 16, 2019) (to be codified at 17 C.F.R. pts. 1, 39, 140).

290 See Saguato, The Ownership of Clearinghouses, supra note 8, at 614-16, 635-40.

291 See id. at 659-61.

292 See id. at 658-65.

293 See Accountable Capitalism Act, S. 3348, 115th Cong. (2018).

294 See Saguato, The Hidden Costs of Clearinghouses, supra note 8 (manuscript at 39-54). 
resilience. ${ }^{295}$ Some insightful articles have contributed to the debate that led to the existing regime. Interestingly, almost all of the contributions share two premises and one lapse. Some papers share concerns about the potential conflicts of interest and excessive market power that might result from the direct involvement of large financial institutions in the governance of clearinghouses, as well as the tensions between clearinghouses' public service role as systemic risk managers and the for-profit nature of these corporations. ${ }^{296}$ In addition, some authors rely on a more direct intervention of regulators in the governance and running of clearinghouses, either justifying it based on the inevitable intervention of public money as financial support-i.e., as a bailout-if a clearinghouse were to fail, 297 or on the systemic relevance and public policy function of clearinghouses. ${ }^{298}$ However, all such contributions have overlooked the agency costs that result from the separation of risk and control in clearinghouses and clearinghouse members' incentives for encouraging effective clearinghouse risk management.

Professor Kristin Johnson identifies the possible "tension[s] [that can] emerge[] between clearinghouses' public service role and their private ownership structure," focusing specifically on the tension between their profit-maximization objective and self-regulatory function. ${ }^{299}$ In addition, by focusing on the role of large clearing members in the governance of

295 See, e.g., Colleen M. Baker, Incomplete Clearinghouse Mandates, 56 Am. Bus. L.J. 507 (2019); Greenberger, supra note 9; Griffith, supra note 9 (focusing on the implications of different governance structures on firms' risk management); Johnson, Governing Financial Markets, supra note 9; Saguato, The Ownership of Clearinghouses, supra note 8.

296 See, e.g., Greenberger, supra note 9, at 263-68; Johnson, Clearinghouse Governance, supra note 9, at 696-701; Johnson, Governing Financial Markets, supra note 9, at 221-29. However, these articles overlook the critical agency costs and structural fragilities that stem from the separation of final risk bearing and control rights in clearinghouses' organizational structure.

297 See Lubben, Failure of the Clearinghouse, supra note 9, at 130-33, $153-57$.

298 See Griffith, supra note 9, at 1235-39; see Johnson, Governing Financial Markets, supra note 9, at 225-33.

299 Johnson, Governing Financial Markets, supra note 9, at 221. 
clearinghouses and discussing concerns surrounding their dominance in the derivatives markets, she claims that the members' presence contributes to potential conflicts between "regulators' expectations and . . clearinghouse owners' priorities," which might result in anti-competitive behaviors by member-owners and in weak risk management policies, and could ultimately "engender moral hazard concerns, and create systemic risk." 300 Contributing to the post-crisis academic discussion-and, on the one hand, joining the view that derivatives dealers' influence in markets has to be reduced, while on the other arguing that regulators are better positioned to effectively monitor risk-Professor Johnson supports the appointment (by federal regulators) of a special clearinghouse director, functioning as a board monitor and designated to participate in clearinghouses' decision-making process. ${ }^{301}$ This special director would report directly to (and be paid by) the federal agency responsible for overseeing the clearinghouse's compliance with Title VII. ${ }^{302}$ Despite providing a very insightful perspective on the debate over clearinghouse governance and highlighting the delicate conflict between clearinghouses' role as self-regulatory organizations and for-profit market players, this analysis focuses almost exclusively on the claimed anti-competitive incentives of large clearing members to foreclose market entry to new participants. It substantially overlooks the potential conflicts of interest between members and shareholders and destabilizes the incentives that the final risk-bearers of the clearinghouse-i.e., the members-have in creating a safe and sound institution with resilient and reliable risk-management mechanisms.

A second noteworthy contribution to the discussion on clearinghouse governance comes from Professor Sean Griffith, who identifies the moral hazard and free-riding problems that might arise when control and exposure to risk are not aligned, and highlights the shortcomings of existing clearinghouse governance arrangements to solve these problems. ${ }^{303}$

\footnotetext{
300 Id. at $221,225$.

301 See id. at 239-41.

302 See id. at 240.

303 See Griffith, supra note 9, at 1219-1221, 1239-40.
} 
However, Professor Griffith is primarily focused on the influence and control that derivatives dealers might have over clearinghouse governance, ${ }^{304}$ and not on the moral hazard that spills from the separation of ownership and risk-bearing. Looking at the German experience of codetermination and the two-tiered board structure adopted by German firms, ${ }^{305}$ Professor Griffith provides a governance compromise solution to manage systemic risk. He offers a new governance structure that envisions the presence of two different classes of directors within a clearinghouse's board: traditional directors, who owe fiduciary duties to shareholders and are elected by them, and a second class of "supervisory directors," "charged with the public role of overseeing systemic risk," who are elected by federal regulators and accountable to the public interest in systemic stability. ${ }^{306}$ Professor Griffith does not envision the direct participation of regulators in the governance of clearinghouses, but proposes that regulators shall identify and elect parties with knowledge and expertise in the clearing business to be responsible for supervising systemic risk. ${ }^{307}$

\section{B. Some Policy Proposals}

Without doubt, it has to be recognized that clearinghouses have concentrated risk and have become systemically important infrastructures in post-crisis financial markets. Clearinghouses have to be systemically resilient because of the public policy function assigned to them by lawmakers. Their unique capital profile, however, creates fragility. The misalignment of final risk-bearing costs and control rights

304 See id. at 1197-1204, 1208-09.

305 See e.g., Paul Davies \& Klaus Hopt, Non-Shareholder Voice in Bank Governance: Board Composition, Performance, and Liability, in GoverNANCE OF FinANCIAL InstituTions 117 (Danny Busch et al. eds., 2019); Jens Dammann \& Horst Eidenmüeller, Codetermination: A Poor Fit for U.S. Corporations 8-10 (Eur. Corp. Governance Inst., Law Working Paper No. 509/2020, 2020), https://papers.ssrn.com/sol3/papers.cfm?abstract_id=3565955 [https://perma.cc/PZD3-HAJK].

306 See Griffith, supra note 9, at 1235-1239. This proposal is a multistakeholder corporate governance model defined primarily by a dual-board, two-tier board, based on the German system. See id. at 1235, 1238-39.

307 See id. at 1237. 
among clearinghouse stakeholders increases clearinghouses' moral hazard; the limited equity contributions and skin-inthe-game of shareholders, and the imposition of firms' entire loss-absorbing capacity on clearing members-which do not have, per se, any control rights over firms' risk managementincrease the risk of costs being externalized onto clearing members. This unbalanced economic and organizational structure, compounded by the systemic role of clearinghouses, creates a new manifestation of systemic risk that has been ignored-or, more accurately, overlooked-by crisis-driven regulation. 308

The obvious next step in this discussion is to determine how clearinghouses can be made more resilient and how moral hazard can be reduced in clearinghouses with demutualized ownership but mutualized losses. Policymakers should have paid more attention to the internal structure of clearinghouses and their historical evolution when drafting Titles VII and VIII of Dodd-Frank. Rather than crystallizing the status quo of the for-profit organizational structure of clearinghouses, policymakers should have more thoroughly investigated the potential effects of decoupling final risk-bearing costs and control rights on the risk-taking profile clearinghouses. Recently, the industry has been more active in trying to advance a dialogue on the open issues pertaining to the resilience, recovery, and resolution of clearinghouses. ${ }^{309}$

308 As previously discussed, in the aftermath of the financial crisis, lawmakers were effectively held captive by the political pressure to heavily regulate and punish derivatives dealers who, according to the crisis narrative, were the main cause of the financial crisis. See FIN. CRISIS INQUIRY Comm'N, supra note 191. See also supra notes 178-181 and accompanying text. This resulted in a restrictive conception of derivative dealers' governance rights in clearinghouses. See supra notes 202-210 and accompanying text.

309 See ABN-AMRO Clearing et Al., A Path Forward For CCP ResilIENCE, RECOVERY, AND RESOLUTION (2020), https://www.jpmorgan.com/jpmpdf/1320748249038.pdf [https://perma.cc/4ALU-V8ZL]; Marnie Rosenberg et AL., A Balancing ACt: Aligning Incentives Through Financial Resources for Effective CCP Resilience, Recovery AND RESOLUTION (2017), https://www.jpmorganchase.com/corporate/news/document/Office-of-Regulatory-Affairs-CCP-White-Paper.pdf? source=Office-of-Regulatory-Affairs-ISPgTile 
How can these incentives be better aligned? And how can moral hazard be mitigated? This Article identifies five possible solutions that could create safer and sounder clearinghouses, each of which either implies a different degree of regulatory intervention or would be triggered only in the event of the default or serious distress of a clearinghouse.

The first two policy solutions fall on the extreme ends of the spectrum and focus on clearinghouses' ownership structure: the remutualization of clearinghouses and the nationalization of clearinghouses. ${ }^{310}$ Both solutions address, in different ways, the risk concentration issue and would assign control and governance rights to the stakeholders who are likely to be the final risk-bearers of the clearing business. The third and fourth policy solutions would address the internal resilience of clearinghouses and affect shareholders' skin-inthe-game contributions ${ }^{311}$ and members' control rights, ${ }^{312}$

[https://perma.cc/9H5J-CEQX]; BARBARA Novick ET AL., RESILIENCY, RECOVERY, AND Resolution: Revisiting the 3 R's for Central Clearing CounTERPARTIES (2016), https://www.blackrock.com/corporate/literature/whitepaper/viewpoint-ccps-resiliency-recovery-resolution-october-2016.pdf [https://perma.cc/57FT-2GFL]. See also Gillian Tett, Banks are Right to Say That Clearing Houses are Ripe for Reform, Fin. TIMEs (Oct. 24, 2019), https://www.ft.com/content/f6712622-f5b4-11e9-9ef3-eca8fc8f2d65

[https://perma.cc/4VYU-WC3U]; Philip Stafford, Banks and Investors Push for Clearing House Reforms, Fin. Times (Oct. 24, 2019), https://www.ft.com/content/a502be00-f64e-11e9-9ef3-eca8fc8f2d65 [https://perma.cc/NZ9D-QNAC].

310 These policy solutions are modeled on the discussion in Saguato, The Ownership of Clearinghouses, supra note 8, at 658-61, 665-66.

311 There are other areas of Dodd-Frank that require the "risk producer" to put skin-in-the-game to reduce the risk of moral hazard and externalization of losses. Securitizations are one example where regulators require skin-in-the-game by the issuer of the securitized assets, the socalled risk-retention rule. See Standard Risk Retention, 17 C.F.R. § 246.4 (2016). Skin in the game operates as a mechanism to reduce the risk and cost of asymmetry of information and moral hazard. See Saguato, The Ownership of Clearinghouses, supra note 8, at 643-44.

312 See Professor Paolo Saguato, Comment Letter on Proposed Rules on Derivatives Clearing Organization General Provisions and Core Principles 2 (Sept. 13, 2019), https://comments.cftc.gov/PublicComments/ViewComment.aspx?id=62190\&SearchText= [https://perma.cc/2TJX-G6JH] . 
respectively. Finally, the fifth solution tackles the existence of clearinghouses within larger infrastructural groups. ${ }^{313}$

\section{The Remutualization of Clearinghouses}

The remutualization of clearinghouses, which I discussed in more detail in my previous work, would match the role of member and shareholder. ${ }^{314}$ In doing so, the agency costs that result from the separation of control and risk-bearing between members and shareholders would be completely reconciled. Full internalization of the clearing business would be achieved, and clearinghouses would again don the garb of a private-ordering mechanism. ${ }^{315}$ However, in the current environment, direct remutualization is highly unlikely. First, sections 726 and 765 of Dodd-Frank prevent clearing members (i.e., swap dealers) from acquiring control or voting rights in clearinghouses. ${ }^{316}$ Even without the final rules being implemented, these provisions are an insurmountable barrier for remutualization. Also, as previously mentioned, clearinghouses are now part of large infrastructural groups. ${ }^{317}$ Without a regulatory intervention that would incentivize or force a spin-off of the clearing business from the larger financial group, it is difficult to imagine remutualization as an economically viable option. ${ }^{318}$ In the market environment in which clearing fees are generating substantial revenues for FMI groups, clearinghouse holding companies won't have any

313 For a more in-depth discussion of these last three policy options, see Saguato, The Hidden Costs of Clearinghouses, supra note 8 (manuscript at 39-54).

314 For a more elaborate discussion on the remutualization of clearinghouses, see Saguato, The Ownership of Clearinghouses, supra note 8, at 659-61.

315 See Peirce, supra note 9, at 655-57.

316 See Dodd-Frank Act, Pub. L. No. 111-203, §§ 726, 765, 124 Stat. 1376, 1695-1696, 1796-1797 (2010). See also supra note 201 and accompanying text.

317 See supra note 259 and accompanying text.

318 See generally Baker, supra note 295 (elaborating on recovery mechanisms for clearinghouses and proposing that in order to complete the mandatory central clearing regime, an industry utility for central clearing services should be created). 
incentive to give up one of their more profitable businesses. A back route to remutualization, however, could be the result of a clearinghouse's failure and the intervention of recovery tools, discussed in the following Sections.

\section{The Nationalization of Clearinghouses}

The other "extreme" policy solution would be the nationalization of clearinghouses. ${ }^{319}$ This proposal shares the same rationales of the remutualization option, differing only in its primary assumption. If we assume that public money would very likely be used to sustain a clearinghouse if it faced financial distress, then taxpayers-as the ultimate risk-bearers of clearinghouses' financial risk-should own and run the business. In order to reach the point where one would consider this solution, a clearinghouse would have had to fail. Because a failure of a clearinghouse would reflect on the failure of the post-crisis derivative market regulatory architecture, nationalization would be the only possible path towards keeping the system afloat. Both radical solutions could only be practically implemented during or after a clearinghouse crisis or failure, once the structural fragilities of the clearinghouse's organizational structure and the failure of the regulatory approach were exposed.

\section{Multi-stakeholder Boards}

The third and fourth policy solutions share the same premise: they could be achieved with regulatory action, without the need for Congress's intervention. Critical provisions of the Dodd-Frank Act regarding firms' governance and potential conflicts of interest have not yet been adopted by the competent authorities in the ten years since the financial crisis. ${ }^{320}$

319 For a more comprehensive discussion of the nationalization option, see Saguato, The Ownership of Clearinghouses, supra note 8, at 665-66.

320 See Requirements for Derivatives Clearing Organizations, Designated Contract Markets, and Swap Execution Facilities Regarding the Mitigation of Conflicts of Interest, 75 Fed. Reg. 63,732 (proposed Oct. 18, 2010) (to be codified at 17 C.F.R. pts 1, 37-40); Governance Requirements for Derivatives Clearing Organizations, Designated Contract Markets, and Swap Execution Facilities; Additional Requirements Regarding the Mitigation of 
These pending rulemakings could be the right opportunity for regulators to complete the clearinghouse regulatory framework, address the current issues in the system, fix the existing rules, and create more resilient clearinghouses. ${ }^{321}$

Clearinghouses should adopt a hybrid governance structure that would reflect their double-layered capital. One of the core principles of the post-crisis regulatory regime is the representation of market participants on clearinghouses' governing boards and committees. ${ }^{322}$ This policy option would result in greater market participants representation by granting clearing members voting rights proportionate to the amount of contributions made to the guaranty fund. As investments in the equity capital of clearinghouses' holding companies assign voting rights to firms' shareholders, so should contributions to the guaranty fund assign proportional and special voting rights to clearing members. A possible mechanism could be the following: special hybrid financial instruments should be given to members, and voting rights should be assigned for the election of members' representatives to the different risk committees and to the board itself. One-third of directors should be elected by clearing members, and the board should be composed of a majority of clearing member (and end-user) representatives. ${ }^{323}$

Regulators and clearinghouses should consider the importance of strengthening the role and voice of risk committees. Their decision-making power should be made more binding than that of simple advisory boards by requiring the governing board, anytime it dissents from the decision of its risk committee, to provide formal and comprehensive

Conflicts of Interest, 76 Fed. Reg. 722 (proposed Jan. 6, 2011) (to be codified at 17 C.F.R. pts $1,37-40)$.

321 As previously discussed, currently both the CFTC and SEC regimes fall short in addressing the misaligned incentives of clearinghouses and in creating robust recovery and resolution mechanisms for clearinghouses in distress. See supra Section IV.A.

322 See 7 U.S.C. $\S 7 \mathrm{a}-1(\mathrm{c})(2)(\mathrm{Q})$ (2018).

323 See ABN-AMRO CLEARING ET AL., supra note 309, at 5-6 (advocating for governance arrangements that capture input from clearing members and end users). 
explanations of its decision to the market participants (clearing members and their users) and the competent regulator.

If members were empowered to govern and police the risk profile and management of clearinghouses, they would be more inclined, or at least less resistant, to accept the operation of the loss mutualization mechanism. ${ }^{324}$ This would rebalance the for-profit nature of clearinghouses with their unique lossallocation mechanisms.

\section{A New Capital Structure for Clearinghouses: Convertible Debt and Capital Requirements}

In order to have their risk-taking incentives aligned with those of their members, clearinghouses' shareholders should be subject to a contingent liability regime. ${ }^{325}$ Instead of having clearing members replenish the exhausted guaranty fundand even before subjecting them to assessment rights or imposing haircuts on their margins-clearinghouses' shareholders should be responsible for the re-funding of the guaranty fund. In doing so, shareholders would have contingent skinin-the-game in the business and would be incentivized to effectively monitor the risk of the clearing business and to implement robust risk models. ${ }^{326}$ A practical implementation of this solution could be built around the issuance by

324 See Saguato, The Ownership of Clearinghouses, supra note 8, at 664-65.

325 This solution to the agency costs between members and shareholders was inspired by the seminal work of Professors Miller and Macey on the early $19^{\text {th }}$ century double liability regime of bank's shareholders. See Jonathan R. Macey \& Geoffrey P. Miller, Bank Failures, Risk Monitoring, And the Market for Bank Control, 88 Colum. L. REV. 1153, 1202-23 (1988); Jonathan R. Macey \& Geoffrey P. Miller, Double Liability of Bank Shareholders: History and Implications, 27 WAKE FOREST L. REV. 31 (1992); Jonathan R. Macey \& Geoffrey P. Miller, Double Liability of Bank Shareholders: A Look at the New Data, 28 WAKE Forest L. REV. 933 (1993). For a response to the work of Professors Miller and Macey, see Howell E. Jackson, Losses From National Bank Failures During the Great Depression: A Response to Professors Macey and Miller, 28 WAKE Forest L. REV. 919 (1993).

326 See Saguato, The Ownership of Clearinghouses, supra note 8, at $662-64$. 
clearinghouses of convertible contingent bonds ("co-cos") ${ }^{327}$ to their shareholders in an amount equal to the size of their guaranty fund. ${ }^{328}$ Shareholders should be required to purchase and hold the co-cos, which would pay interest out of collected clearing fees. The proceeds of the sales of the co-cos should be kept as reserves and invested by clearinghouses in safe assets, secured financing transactions, or in deposit accounts. Co-cos would convert into guaranty fund contributions when a clearinghouse taps into its guaranty fund to cover losses caused by the default of one or more of its clearing members. At that point, the clearinghouse would be required to issue new co-cos, and the non-defaulted members would, in turn, be required to purchase the newly issued co-cos that would match the amount of the converted ones. ${ }^{329}$ This policy solution would directly affect clearinghouses' resilience,

327 See Stefan Avdjiev et al., CoCos: A Primer, BIS Q. REv., Sept. 2013, at 43 .

328 For a general discussion of the role of co-cos in banking capital, see John C. Coffee Jr., Systemic Risk After Dodd-Frank: Contingent Capital and the Need for Regulatory Strategies Beyond Oversight, 111 CoLUM. L. REV. 795 (2011); Charles W. Calomiris \& Richard J. Herring, How to Design a Contingent Convertible Debt Requirement That Helps Solve Our Too-Big-toFail Problem, 25 J. APPLIED CoRP. Fin. 39 (2013); Patrick Bolton \& Frédéric Samama, Capital Access Bonds: Contingent Capital With an Option to Convert, 27 ECON. POL'Y 275 (2012); George M. von Furstenberg, Contingent Capital to Strengthen the Private Safety Net for Financial Institutions: Cocos to the Rescue? (Deutsche Bundesbank Series 2: Banking and Fin. Studies, Discussion Paper No. 01, 2011), https://ssrn.com/abstract=2794056 [https://perma.cc/3PPY-RQ3J]; Suresh Sundaresan \& Zhenyu Wang, On the Design of Contingent Capital with a Market Trigger, 70 J. Fin. 881 (2015); Robert L. McDonald, Contingent Capital with a Dual Price Trigger, 9 J. FIn. Stability 230 (2013); Robert A. Eisenbeis, Bailouts, CAPital, or CoCos: Can Contingent Convertible Bonds Help Banks Cope with Financial STRESS? (2019), https://www.cato.org/publications/policy-analysis/bailoutscapital-or-cocos-can-contingent-convertible-bonds-help-banks [https://perma.cc/AYE2-S6K6]; Fin. STABILITY OvERSight CounCIL, REPORT To Congress on Study of Contingent CAPITAL REQUIREMENT For CERTAin Nonbank Financial Companies And Bank Holding Companies (2012).

329 The issuance of "bail in"-able long-term debt securities can be also envisioned as a mechanism to recapitalize a clearinghouse and to complete the remutualization of the firm by requiring clearing members to underwrite these issued convertible securities. 
increase shareholders' skin-in-the-game, align members' incentives to those of shareholders, and create a counter-cyclical mechanism to recapitalize the clearinghouse in a situation of severe financial distress. ${ }^{330}$

\section{Ring-fencing and Intra-group Guarantee}

Two other solutions policymakers should consider are: (i) requiring clearinghouses to be ring-fenced entities and (ii) requiring clearinghouses' holding companies to guarantee the liability and solvability of their clearinghouses. Ring-fencing would prevent the FMI group from leveraging the clearing business to invest in risky activities, but it would also reduce the risk of spillovers from the clearing business to the rest of the FMI group's activities and vice-versa, and it would simplify the oversight of the clearing business. ${ }^{331}$ In addition, policymakers should adopt for financial market infrastructural groups the same approach used in banking groups and embrace the so-called "source of strength" doctrine, which requires, in the banking context, holding companies to provide financial support to their banking subsidiaries. ${ }^{332}$ In other words, the listed holding company that controls the clearinghouse should be the last source of safety and soundness for the market infrastructure. ${ }^{333}$

330 For a more comprehensive discussion on capital regulation and on how to strengthen clearinghouses' economic resilience, see Saguato, The Hidden Costs of Clearinghouses, supra note 8 (manuscript at 50-54).

331 See generally Steven L. Schwarcz, Ring-Fencing, 87 S. CAL. L. REV. 69 (2013).

332 See Statement of Policy Concerning Bank Holding Companies Engaging in Futures, Forward and Options Contracts on U.S. Government and Agency Securities and Money Market Instruments, 12 C.F.R. $§ 225.142$ (2020).

333 See Anat R. Admati et al., Liability Holding Companies, 59 UCLA L. REV. 852, 873-84 (2012) (proposing the introduction of a new type of financial institution, the "limited liability holding company," to guarantee the debts of systemically important financial institutions). 


\section{Recovery and Resolution Mechanisms}

The final and most critical aspect of the current regulatory regime is the approach to clearinghouses' recovery and resolution. ${ }^{334}$ When a clearinghouse faces recovery or resolution, the agency costs of the separation of ownership and control are magnified, while the interests and incentives of shareholders and members polarize. When all pre-funded financial resources have been used to cover the losses of a defaulted member and a clearinghouse is facing a situation of severe financial distress, then recovery and resolution tools are deployed to support the continuity of the clearinghouse's essential services. However, the package of regulatory solutions to support the continuation of the clearing business of a clearinghouse in severe distress is incomplete and miscalibrated.

In addition to the operation of the default waterfall, the existing recovery tools that clearinghouses have in their rulebooks-namely, assessment rights and a variation margin gains haircut ("VMGH") — are meant to support the financial viability of the firm in a distress scenario. However, as previously discussed, they do not take into account the agency costs introduced by the separation of risk and control and might polarize even more the tensions between clearing members and clearinghouses. Reforming the capital structure of clearinghouses, increasing the amount of VMGH is an interesting, but potentially highly destabilizing, recovery option to rebalance a clearinghouse's matched book. Put simply, in applying a VMGH a clearinghouse would take some collateral posted by its non-defaulted members as margin for their open positions and use that collateral to cover the remaining default losses. The need to use this mechanism would not only reveal that the clearinghouse failed to adopt appropriate risk models, but it would also further exacerbate the moral hazard of the

334 The recovery and resolution toolbox would come into play at the end of the default waterfall, after all margins posted by the defaulted member are liquidated, the resources pledged in the guaranty fund are depleted, and the additional contributions collected via exercising the assessment rights are exhausted. Simply put, a clearinghouse faces a recovery and resolution scenario only if its risk models were completely wrong; accordingly, it would be evident that the firm took on too much risk. 
current structure of clearinghouses. It would do so by externalizing onto clearing members, and not onto shareholders, the risks and losses caused by the firm's failure to set effective risk models. Furthermore, a VMGH would eventually be triggered in a systemic crisis after all mutualization resources were wiped out. Rather than containing the crisis, a VMGH (and in some ways, but in different amounts, assessment rights) would act counterproductively as procyclical tools, exacerbating the risk of fire sales and weakening already fragile market dynamics. ${ }^{335}$

A final comment on the systemic resilience of clearinghouses and the debate on their recovery and resolution. As previously mentioned, a clearinghouse failure is caused by the failure of its risk models (in general), but is usually triggered by the default of one of its clearing members. ${ }^{336}$ The current VMGH approach to dealing with recovery and resolution inspires skepticism because of its procyclical nature. It might stabilize the clearinghouse and contain and absorb the losses of the default of one clearing member, but it would do so to the detriment of the clearinghouse's members and the markets in general. Members would bear all the costs for the mismanagement of the clearinghouse, while shareholders would not be involved in the risk-sharing. In the current regulatory and market environment, clearinghouses' shareholder equity remains completely shielded from any possible losses; clearing members are on the hook and are required to keep the clearinghouse afloat, possibly indefinitely. ${ }^{337}$

335 VMGH would be triggered after a billion dollars' worth of collateral has already been sold on the market, likely at a discount price; therefore, VMGH would be triggered in a market with pre-existing fire-sale activities. See Dermot Turing \& Manmohan Singh, The Morning After-The Impact on Collateral Supply After a Major Default 9 (Int'l Monetary Fund, Working Paper No. 18/228, 2018). The result is to require even more collateral to be trimmed from the already-pledged margins. See id. As a result, the existing open positions with the clearinghouse are left undercollateralized, which exposes the clearinghouse to even more fragility.

336 It is also possible that a clearinghouse would fail because of operational risk.

337 See Dermot Turing, What Do We Do With Troubled CCPs?, 70 VAND. L. REV. EN BANC 279, 280 (2017). 
Reassessing the unstable organizational structure of clearinghouses should be a priority for policymakers. Reducing risk-taking incentives and containing agency costs between members and shareholders would reduce the likelihood of initiating recovery and resolution actions. When recovery and resolution tools may at some point have to be deployed, they should allocate all losses onto a clearinghouse's members, leaving the firm's shareholders off the hook.

Finally, policymakers should focus their attention not just on the node of the system - the clearinghouse-but also on its links. ${ }^{338}$ Rather than debating whether or not clearinghouses qualify for the special bankruptcy regime of Title II of DoddFrank, policymakers should carve out special rules for the treatment of a clearing member's obligations to its clearinghouse. In other words, if a clearinghouse faced distress and one or more of its members defaulted, it is very likely that the whole system would be facing distress, including and especially clearing members. Regulators should strengthen the legal obligations of members to fulfill their assessment rights, particularly in the case where a clearing member is under a recovery and resolution regime. A better alignment of riskbearing costs and control rights, achieved through one of the four policy solutions described above, would increase firms' incentive to build more robust buffers of loss-absorbing resources and to invest in alternative risk-sharing and hedging mechanisms-i.e., insurance. ${ }^{339}$

\section{CONCLUSION}

Clearinghouses are the central nodes in the post-crisis derivatives markets. While in the pre-crisis markets financial risk was spread across the system, the risk of dealing in derivatives is now concentrated in clearinghouses. This new architecture makes it more efficient for regulators and

338 See Saguato, The Hidden Costs of Clearinghouses, supra note 8 (manuscript at 55-59) (analyzing the recovery and resolution mechanisms and the systemic resilience of clearinghouses within the broader network of financial markets).

339 See id. (manuscript at 60-63) (offering a comprehensive discussion of clearinghouses' proposals for recovery and resolution reform). 
supervisors to monitor risk and eventually intervene. However, it makes the firms entrusted with keeping the market functioning, and the management of the risk therein, systemically important.

Ten years after the crisis, systemic risk has been reduced, but it has not disappeared: it has been transformed and centralized in systemic risk managers. Crisis-driven reforms, which focused on reducing the impact and role of systemically important financial institutions, miscalibrated the regulation of clearinghouses' internal governance and financial capital. The agency costs between clearinghouses' shareholders and members (the former participating in the profits of the business, and the latter bearing its final costs) increase the moral hazard of these institutions and threaten clearinghouses' systemic resilience. This Article recommends that policymakers more effectively reassess the internal organization of clearinghouses in order to better align the incentives of shareholders with those of clearing members. 